\title{
Potential Areas for Managed Aquifer Recharge in the Eastern Lower Jordan Valley Area
}

\author{
Elias Salameh*, Ghaida Abdallat \\ National Center for Research and Development (NCRD), Amman, Jordan \\ Email: *salameli@ju.edu.jo
}

How to cite this paper: Salameh, E. and Abdallat, G. (2020) Potential Areas for Managed Aquifer Recharge in the Eastern Lower Jordan Valley Area. Journal of Water Resource and Protection, 12, 330-357. https://doi.org/10.4236/jwarp.2020.124020

Received: March 12, 2020

Accepted: April 18, 2020

Published: April 21, 2020

Copyright $\odot 2020$ by author(s) and Scientific Research Publishing Inc. This work is licensed under the Creative Commons Attribution International License (CC BY 4.0).

http://creativecommons.org/licenses/by/4.0/

\begin{abstract}
The article deals with the feasibility of using the recent geological formations in the eastern Jordan Valley for water storage through artificial recharge due to water scarcity and water needs in this area. Water storage in surface reservoirs in arid and semi-arid areas is afflicted with a variety of issues such as high evaporation, eutrophication processes and exposure to contamination and accidents. Dams to capture all rare-event floods are, generally, big and expensive structures. Artificially recharging aquifers and storing the water in the underground offer a competing alternative. In this study, hydrogeological, geological, geophysical and hydrochemical investigations were carried out to study the potentials of the eastern side of the Lower Jordan Valley for artificial recharge. The results reveal that relatively extended areas on the eastern side of the Lower Jordan Valley have the potential to accommodate large amounts of recharge water and that the impacts of artificially storing the water in aquifers are to be judged very positive compared to surface storage, especially when the amounts of available recharge water can quantitatively be accommodated in recharge facilities. In addition, the study shows, the advantages of underground water storage compared to surface storage in dams. The potential storage capacities in the different parts of the Lower Jordan Valley are quantified based on rechargeable aquifer volumes and porosities. The potential uses of the recharged water are also elaborated on depending on recharge and aquifer water qualities.
\end{abstract}

\section{Keywords}

Managed Aquifer Recharge (MAR), Jordan Valley, Potential Storage, Hydrogeological Conditions

\section{Introduction}

The increasing demand on water for a variety of uses such as drinking, industry, 
irrigation flushing of soils and aquifers, minimizing salt water intrusions and replenishing and improving existing groundwater quality require additional water. On the other hand, the excessive availability of water in certain areas and times of a year makes it imperative to find suitable storage for that water to cover the demand. Artificial groundwater recharge is a way to feed existing aquifers with water to cover the increasing demand on it. Worldwide, artificial groundwater recharge is widely used as a suitable technique to store and protect water from evaporation and pollution and to use that water for the purpose it is stored for.

Enhancement of surface water storage in underground aquifers has developed throughout the last century in different parts of the world and for a variety of purposes by using different ways and techniques. Small-scale river bank storage and recovery date back to many thousand years in semi-arid and arid regions [1]. But, large scale plants using electrical pumps to extract water are less than 100 years old and have been in operation mainly in Central and North Europe.

The increasing demand on water, overexploitation of groundwater aquifers, climate change and availability of water in certain places and times and not in others made it necessary to consider managed aquifer recharge as a viable solution for water storage and recovery. The extensive work of Asano [2] gives a detailed account about the state-of-the art studies, technologies and implementation of MAR projects.

Heviánková [3] published a comprehensive study about groundwater recharge with surface water and its relevance to alleviate impacts of climatic changes in Europe as well as world-wide. They described techniques and methods to recharge aquifers to restock groundwater sources using surface water available in streams. The work also defined the boundary and operation conditions of the used MAR technologies. Huber [4] elaborated on the hydrogeological features necessary for adequately selection of sites for MAR and provided objective criteria for the hydrogeological features encountered in reality which makes a site-by-site approach indispensable.

Many studies have addressed MAR under the conditions prevailing climatic and hydrologic conditions in certain parts of the world. These studies give very valuable experiences for successful MAR projects in specific climatic zones of the globe and they have to be considered when planning MAR projects [5]-[10].

The need for and the conditions of successful managed aquifer recharge (henceforth MAR) projects and their relevance to the prevailing circumstances in Jordan are summarized below [11].

\subsection{Need for Groundwater Artificial Recharge}

Needs for groundwater artificial recharge or managed aquifer recharge, in general, can be summarized in the following points:

1) Storage for available water in times and its need in others;

2) Create temporary storage of water (River bank infiltration);

3) Alleviate salt water intrusions; 
4) Partial treatment of impaired water qualities;

5) Improving the quality of groundwater by recharging it with water of better quality;

6) Relief flooding effects;

7) In addition, water is pumped into oil and gas fields to enhance their productivity.

Points (1), (2), (3) and partially (4) of the above apply to the case of the Jordan Valley area in Jordan.

\subsection{Conditions for Groundwater Artificial Recharge}

1) Need for recharge must be there;

2) Availability of water for recharge;

3) Suitable aquifers are there;

4) Depending on the purpose of recharge, extraction potentials of the recharged water must be given;

5) Necessity and potentials of pre-treatment;

6) Suitable topographic set-up;

7) Conveyance facilities for water to reach recharge sites;

8) Potential for the construction of recharge structures;

9) Depending on the purpose of recharge, water quality of rechargeable aquifers, quality of vadose zone and quality of recharge water must be appropriate;

10) Construction, maintenance and repair capabilities and financial affordability.

For the Jordan Valley area all above points, 1 - 10 must be fulfilled in order to go ahead with any groundwater artificial recharge schemes. These conditions will be discussed in the following (without a special order).

\subsection{Characteristics of the Study Area}

\subsubsection{Topography}

The Lower Jordan Valley is a flat flood plain extending from Lake Tiberias in the north to the Dead Sea in the south with a length of $105 \mathrm{~km}$ and a width of 4 - 30 $\mathrm{km}$, as depicted in Figure 1. In the middle of that flood plain the Jordan River has, during the Holocene, cut its meandering course to form a topographic depression of 10 - $30 \mathrm{~m}$ below the JV level and up to $500 \mathrm{~m}$ in width called locally the Zoor area (Figure 2). The meandering JR has a length of $217 \mathrm{~km}$. The overall slope of the JV is $1.81 \%$ but due to meandering, the length of the JR itself has an average gradient of $0.86 \%$ which is a very high gradient contradicting the meandering nature of the river in geomorphologic considerations.

The Jordan Valley is bordered on both sides by high, steep mountains with differences in elevations between the valley floor and the surrounding mountains of 1000 to $1500 \mathrm{~m}$.

The main features of the JV area are the relatively flat terraces on both sides of the JR, which constitutes the bed of the valley (Figure 2). 


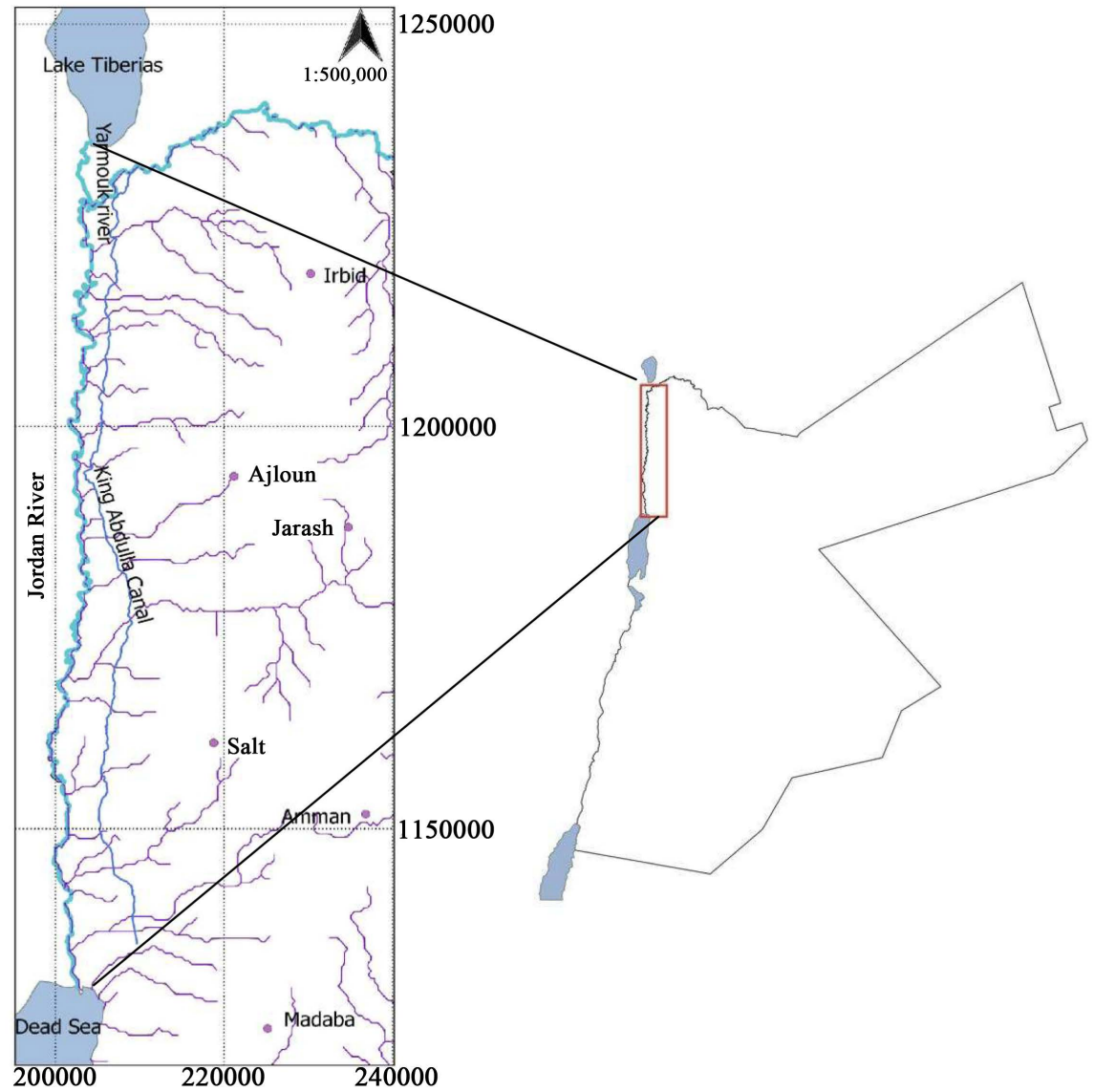

Figure 1. Location map of the Jordan Valley in Jordan.

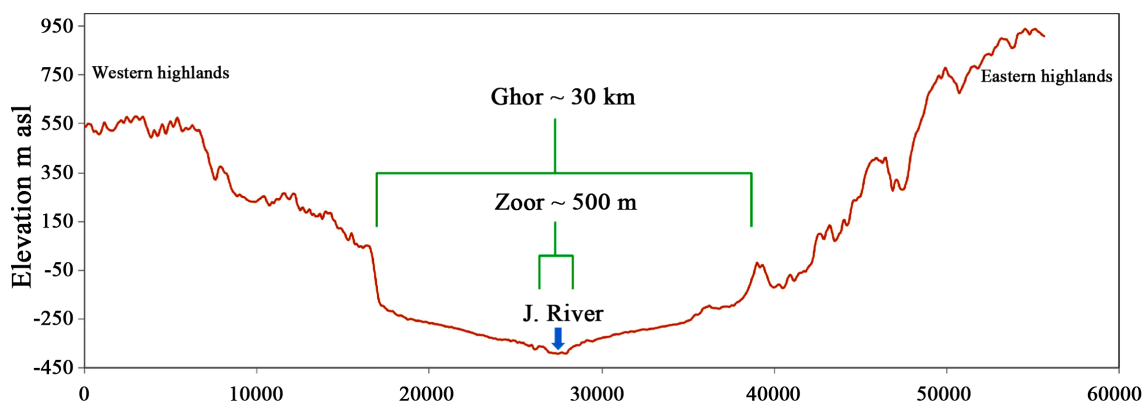

Figure 2. General topographic E-W cross-section through the Jordan Valley.

\subsubsection{Climate}

Due to its position of $200-400 \mathrm{~m}$ below sea level, the JV area enjoys a unique climate totally differing from the climate of its surrounding mountains in the east and west. Information about the climate in the area has been obtained from the Department of Meteorology (DOM)/Ministry of Transport [12].

The mean maximum annual temperature in the $\mathrm{JV}$ area is $31.5^{\circ} \mathrm{C}$ (January) and the mean maximum monthly temperature in summer is $38.8^{\circ} \mathrm{C}$. The highest ever registered temperature is $52^{\circ} \mathrm{C}$. In winter temperatures during the night may drop to a few degrees centigrade or even reach the freezing point. In the northern part of the valley the average temperature is $1.8^{\circ} \mathrm{C}$ less than that in the 
southern part with the highest registered temperature of $51.2^{\circ} \mathrm{C}$ and the lowest of $-2^{\circ} \mathrm{C}$.

The relative humidity is very low in the southern part with a long term daily mean of $64 \%$ in the coldest period of the year (January and February) going down to $27 \%$ in the hottest summer months at midday. In the northern part the humidity ranges from $30 \%$ during hot summer days to $70 \%$ in the cold winter.

Rainfalls from October to May with a concentration during December to March: The northern JV area receives an average amount of precipitation of about $400 \mathrm{~mm} / \mathrm{yr}$, whereas the southern area receives only about $100 \mathrm{~mm} / \mathrm{yr}$ (Figure 3). In dry years the amount of precipitation in the northern part reaches only $200 \mathrm{~mm} / \mathrm{yr}$ whereas at the shores of the DS it decreases to merely 40 $\mathrm{mm} / \mathrm{yr}$. In rain-rich years precipitation may reach $650 \mathrm{~mm} / \mathrm{yr}$ in the north and $250 \mathrm{~mm} / \mathrm{yr}$ in the south. Snow falls very infrequently in the northern most part of the JV.

As a result of high temperatures and low relative humidity the evaporation force the climate is very high and the potential evaporation ranges from 2400 $\mathrm{mm} / \mathrm{yr}$ at the shores of the Dead Sea to about $2300 \mathrm{~mm} / \mathrm{yr}$ in Lake Tiberias area.

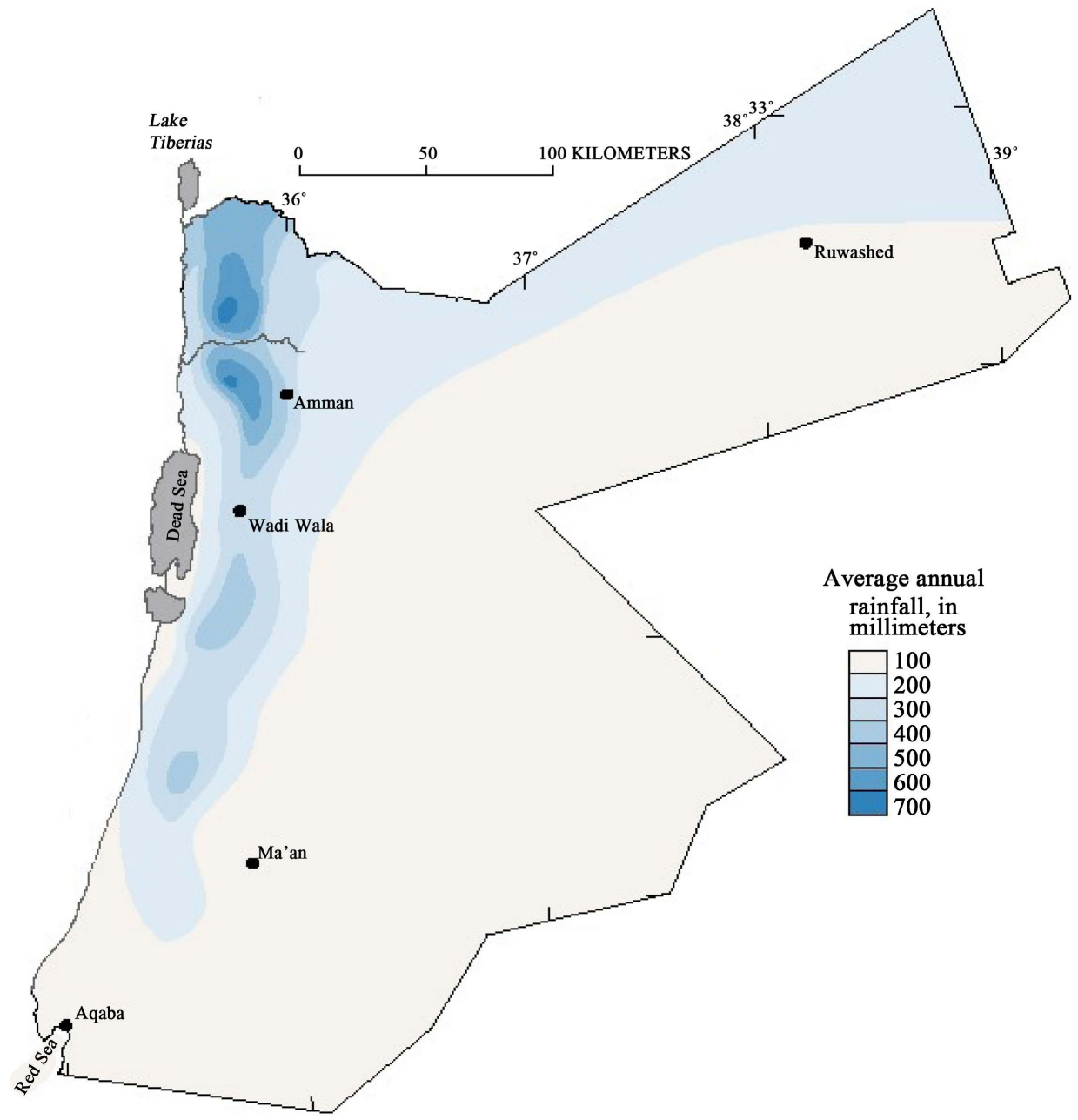

Figure 3. Annual rainfall distribution in Jordan in $\mathrm{mm} / \mathrm{yr}$. 


\section{Geology}

The JV floor consists mainly of nonconsolidated alluvial sediments of gravel, sand, shale marl and clay. In addition, fine salty marls that precipitated from the ancestors of the present DS are found in the form of extensive deposits and lenses, especially in the southern and western parts of the JV at the slopes to the Zoor [13] [14].

The unconsolidated valley sediments are underlain by rocks of Triassic to recent ages (Figure 4). In the different parts at the mountain toes rocks ranging in age from Triassic to Recent crop out with their western extensions covered by the more recent JV deposits. Figure 5(a) and Figure 5(b) show general N-S and $\mathrm{E}-\mathrm{W}$ geologic cross section to illustrate the relative setup of older geological formations to the more recent JV deposits along the Jordan Transform Fault (JTF). Table 1 contains the relevant information about the escarpment foothills formations; rocks, thicknesses and hydraulic properties.

Of importance to the current study are the recent sediments within the Jordan Valley which are generally of Quaternary age. With the start of the formation of the Jordan Valley Depression after the last regression of the Tethys sediments of terrestrial origin started to deposit in that new local base level for surface water. The sediments of relevance to the present study are of Lower Pleistocene and younger ages and are subdivided into the following formations:

Table 1. Geologic formations (F) building the eastern Jordan Valley escarpment; rocks types their thicknesses and hydraulic properties [11] [14] [15] [16].

\begin{tabular}{|c|c|c|c|}
\hline Age & Rock types & Thickness (m) & Hydraulic properties \\
\hline Tertiary & Chalk, marl, limestone & $490-530$ & Detailed below \\
\hline Wadi Shallala F. (B5) & Chalky and marly limestone & 250 & Medium aquifer \\
\hline Rijam F. (B4) & Chalk, chert and limestone & 40 & Only locally an aquifer \\
\hline Upper Muwaqqar F. (B3) & Chalk, marl, chalky limestone with chart nodules & $200-240$ & Aquiclude \\
\hline Upper Cretaceous & Calcareous sediments & $690-910$ & Detailed below \\
\hline $\begin{array}{l}\text { Lower Muwaqqar F. (B3) + } \\
\text { Amman F. (B2) }\end{array}$ & Silicified limestone, chart, phosphate & $30-120$ & Excellent aquifer \\
\hline Wadi Ghudran F. (B1) & Chalks and marls & Up to 70 & Aquiclude \\
\hline Wadi es Sir F. (A7) & Hard massive karstified limestone & 180 & Very good aquifer \\
\hline Shueib F. $(A 5,6)$ & Thick marls alternating with thin bedded limestone & $50-100$ & Aquifuge \\
\hline Hummar F. (A4) & Hard crystalline limestone and dolomitic limestone & $60-120$ & Excellent aquifer \\
\hline Fuheis F. (A3) & Marls and chalks only locally limestone & $70-90$ & Aquiclude \\
\hline Naur F. $(A 1,2)$ & Sandy marl, shale, dolomitic limestone & 230 & $\begin{array}{l}\text { Aquiclude, except some } \\
\text { carbonates forming medium aquifer }\end{array}$ \\
\hline Lower Cretaceous & $\begin{array}{l}\text { Sandstones, some silts and shale, glauconite, } \\
\text { some gypsum, dolomites and limestone }\end{array}$ & 140 & Good aquifer \\
\hline Jurassic & $\begin{array}{l}\text { Sandstone, calcareous sandstone, shale, marl, } \\
\text { dolomite, and limestone }\end{array}$ & 130 & Medium aquifer \\
\hline Triassic & $\begin{array}{l}\text { Sandstone, siltstone, shale, marls, } \\
\text { thin limestone and evaporates, especially gypsum }\end{array}$ & 490 & Good aquifer \\
\hline
\end{tabular}




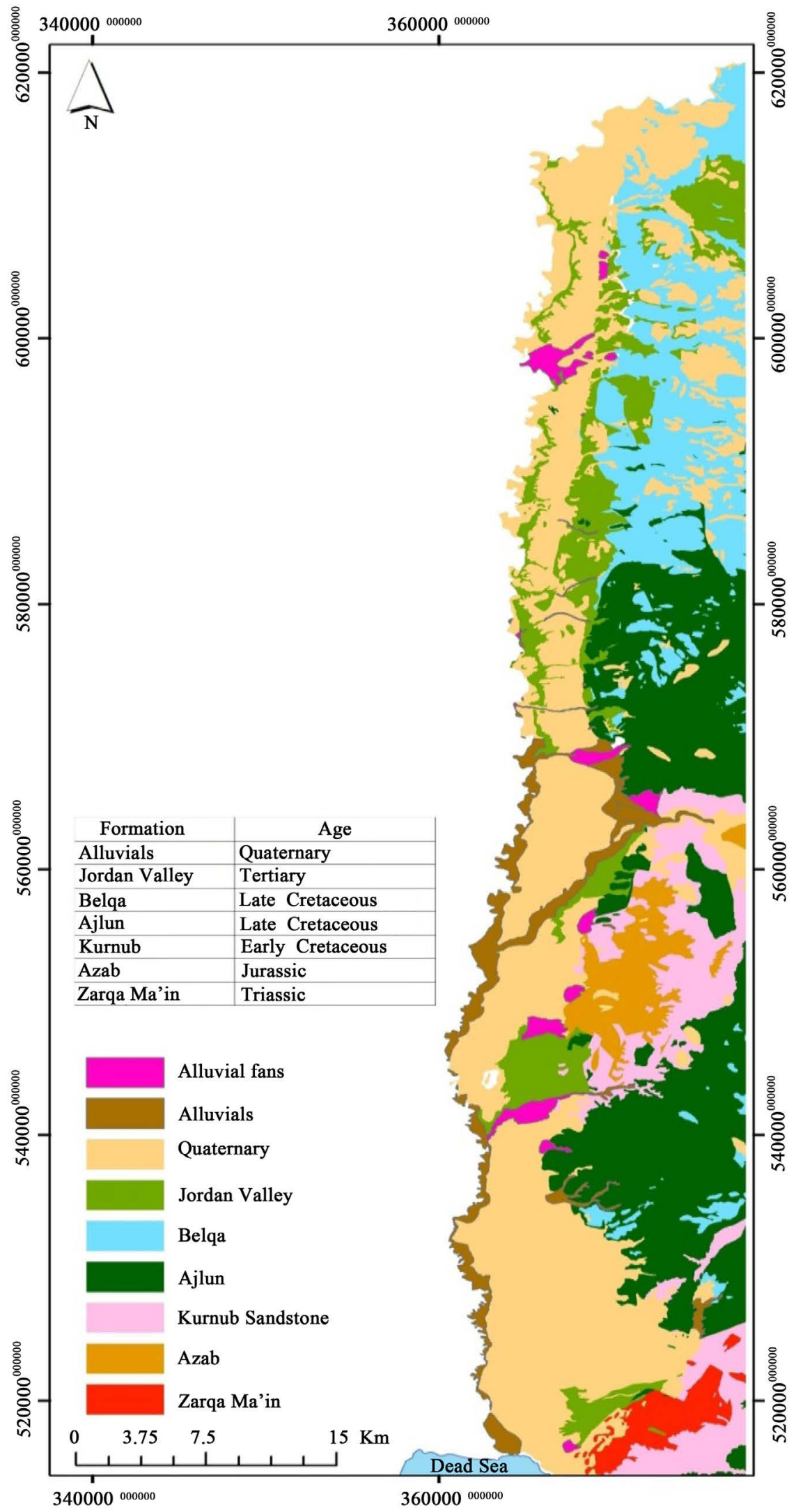

Figure 4. Geological Map of the eastern Lower Jordan Valley and its eastern foothills and highlands (Based on the NRA Geological Maps of Jordan [15]). 


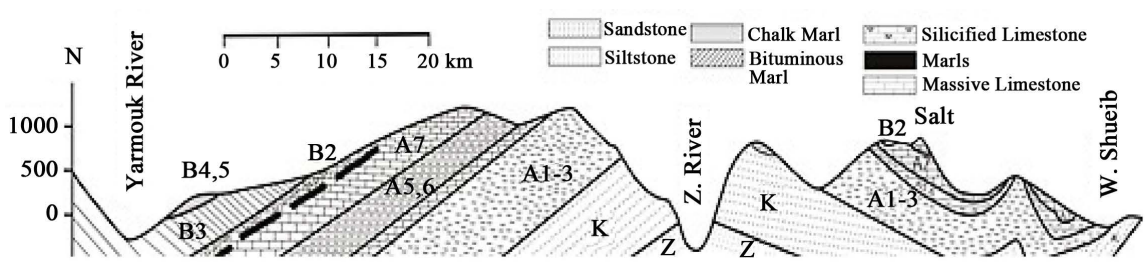

(a)

W

$\mathrm{E}$

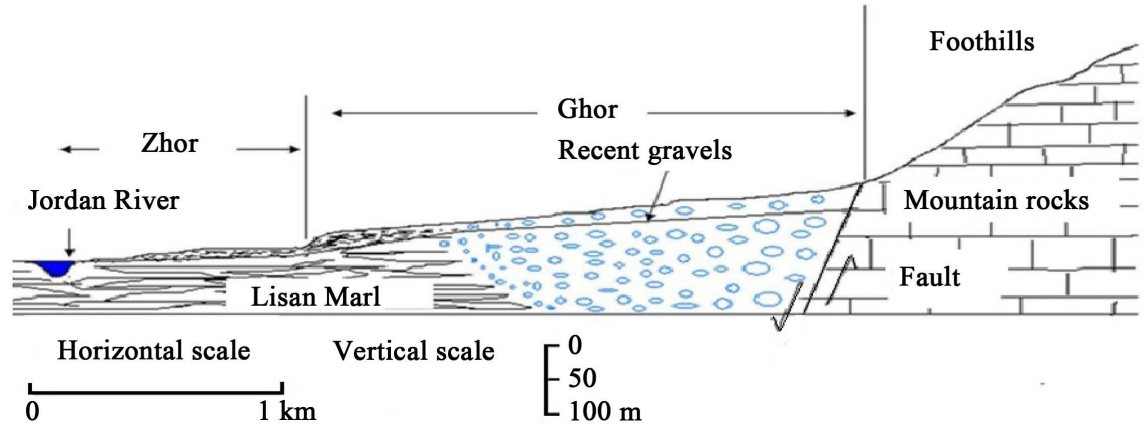

(b)

Figure 5. (a) North South generalized geologic cross section along the eastern foothills of the Lower Jordan Valley, parallel to the Jordan Transform Fault, extending from the Dead Sea in the south to the Yarmouk River in the north showing the main structural features of the eastern highlands and the geologic interfaces with the Jordan Valley area (Z; Triassic and Jurassic, K; Lower Cretaceous, A1 - 3; lower part of Upper Cretaceous, A1 - 7, B1, B2 and lower part of B3; upper part of Upper Cretaceous and part of B3, B4 and B5; Tertiary); (b) East-west generalized geologic cross section from the eastern foothills of the Lower Jordan Valley to the Jordan River showing the relationship of the mountain rocks, in general, to the recent sediments of the Jordan Valley across the Jordan Transform Fault.

\section{Jordan Valley 1 (JV1, Ghor el Kattar and Shagur Conglomerates)}

This formation consists of well cemented conglomerates with low porosities and permeabilities. It was deposited in the Jordan Valley floor, accompanying the faulting and the formation of the depression along the JRV. Ghor el Kattar sediments cover bedrock of different ages at the foot hills of the JV. Their thickness may reach $350 \mathrm{~m}$ (Table 2).

\section{Jordan Valley 2 (JV2, Abu Habil, Kufranja and Samra Formations)}

Abu Habil Formation overlies the JV1 and consists of clastic sediments with a total thickness of some $100 \mathrm{~m}$. Its deposition is related to another tectonic activity along the JRV and overlies the JV1 with an angular unconformity.Kufranja Formation consists mainly of conglomerates of about $100 \mathrm{~m}$ in thickness and in places overlies Abu Habil Gravels. Samra Formation consists of fine to coarse grained clastics covering areas in the surroundings of Zoor area. The groundwater of these Formations is generally saline, except in the areas of the foot hills of the mountainswhere some fresh water can be foundresulting from lateral flows originating from the mountain aquifers to the east.

Jordan Valley 3 (JV3, Lisan Formation) 
Table 2. Recent geologic formations in the eastern Lower Jordan Valley area [11].

\begin{tabular}{cc}
\hline Formation Name & Thickness [m] \\
\hline Alluvial fans and recent deposits & $0-100$ \\
Lisan & 40 - few hundred \\
Samra & 35 \\
Kufranja gravels & 100 \\
Abu Habil series & 100 \\
Ghor El Kattar and Shagur Conglomerates & $\sim 350 \mathrm{~m}$ \\
\hline
\end{tabular}

Lisan Formation was deposited in Lisan Lake which occupied the JV area from about $80.000 \mathrm{yr}$ ago until the end of the Pleistocene and extended from Lake Tiberias in the north to about $45 \mathrm{~km}$ to the south of the southern shore of the DS [13]. The Formation consists of very thin bedded marls; few millimetres in thickness with a total thickness ranging from 40 to more than a few hundred meters.

In the southern half of the Lower JV and to the south of the Dead Sea the deposit is highly gypsiferous, its salt content is high and its groundwater is saline. Old alluvial fans containing fresh water inter-finger with the Lisan Marls. The primary permeability of the formation is low butits secondary permeability along fractures and dissolution channelsis high.

\section{Recent Alluvial Fans}

The recent alluvial deposits of Pleistocene and Holocene ages which cover all older Quaternary depositshave been deposited by the different rivers and wadis at their entrance into the JV areafrom its eastern side. These alluvial fan deposits consist of gravels at their apexes and silt and fine sands at their toes near the Jordan River. This set-up is reflected in the high porosity and permeability at the apexes of the alluvial fans which decrease towards the toes which is in turn is reflected in lower groundwater velocities towards the JR. The thickness of these alluvial fans, as found by drilling and geoelectric sounding, may reach $100 \mathrm{~m}$ at the apexes thinning out towards the toes. Slope debris which originates from mass wasting at the escarpment foothills inter-finger and overlap these alluvial fans. These alluvial fans are the main targeted geological formations for artificial recharge of groundwater.

\section{Volcanic Rocks}

Upper Tertiary and Quaternary basalts cover large extents in northeast Jordan. Bender [13] recognized six phases of basalt flow in north east Jordan. The northern parts of the study area, especially along the Yarmouk Valley, are covered by basaltic rocks forming the west extensions of Harrat esh Sham basalts. Their thickness there reaches few tens of meters covering recent Tertiary and Cretaceous rocks.

Basalts are either directly recharged by rainfall or they receive laterally groundwater from the mountain aquifers, like the basalt aquifer of Adasiya at the entrance of Yarmouk River into the JV. In the central part of the JV a very limited 
basaltic outcrop $\left(500 \mathrm{~m}^{2}\right)$ is found covered by the recent Lisan Marls. They are of negligible importance for MAR projects.

\section{Structures}

The major structural element which has an impact on the set-up of the recent deposits in the JV is the Jordan Transform Fault trending N-S parallel to the Jordan Valley and along which a sinistral strike slip movement has been taking place since Early Pleistocene [17]. This fault transfers the recent sediments of the $\mathrm{JV}$ in a type of flower structure which runs along the central part of the JV in its southern area (DS to Deir Alla) and at the foothills of the eastern mountains in the JV northern area (Deir Alla to Yarmouk). The strike slip sinistral movement along the northern part of the JV has resulted in gradual separation of the alluvial fans and slope debris from their source wadis and mountains. That exposes the alluvial sediments to erosional and depositional processes making the recognition and mapping of the ancient alluvial deposits (shifted by the strike slip movement) by using conventional field methods very difficult. Only indirect methods, drilling, geophysics, water balances may assist in locating suitable sites for MAR.

\section{Hydrology}

\subsection{Surface Water}

Due to its relative flatness, low rainfall and porous rocks cover the JV area produces almost no runoff from precipitation water falling over its southern part. In the northern part runoff is very limited and negligible in terms of harvesting.

The eastern JR tributaries draining its catchment areas which extend into the highlands bring the surface runoffs into the JV (Figure 6). The surface water contributions of the different side wadis to the JV area are given in Table 3 together with the average discharge of inter-catchments. Most of the main wadis dams have been built. Table 4 shows the sites, capacities and year of construction of these dams. The average discharges of downstream catchment areas of existing dams are listed in Table 5. Because the waters of flood flows of inter-catchments (Table 3) and of dams' downstream areas (Table 5) flow unused into the JR and the DS they can serve as source water for MAR.

\subsection{Groundwater}

The Shallow groundwater in the eastern JV area is found in the alluvial deposits composed of clastic sediments originating from the eastern catchments of the JV area [20]. The decreasing gradients from the mountain foothills towards the JR allowed the coarse-grained sediments to deposit at the foothills of the JV and the fine-grained sediments (clays) close to the JR, which resulted in rapidly declining permeability of the sediments towards the JR course. Therefore, the groundwater velocities in these alluvial sediments decrease rapidly in westerly direction. 
Table 3. Average pre-development discharges of side wadis and inter-catchments into the eastern Jordan Valley area MCM/yr [15] [18].

\begin{tabular}{|c|c|c|c|}
\hline Catchment area & Flood flow & Base flow & Total \\
\hline Yarmouk (at Adasiya) & 182 & 218 & 400 \\
\hline El-Arab & 6.48 & 24.90 & 31.38 \\
\hline Ziqlab & 2.2 & 8.3 & 10.5 \\
\hline Yabis & 1.63 & 6.2 & 7.83 \\
\hline El-Jurm & 0.23 & 11.5 & 11.73 \\
\hline Rajib & 1.31 & 3.0 & 4.31 \\
\hline Kufranja & 1.02 & 5.8 & 6.82 \\
\hline Shueib & 1.77 & 8.0 & 9.77 \\
\hline Kafrain & 1.35 & 12.0 & 13.35 \\
\hline Hisban & 0,34 & 6.3 & 6.64 \\
\hline Zerka & 46.52 & 48.3 & 94.82 \\
\hline \multicolumn{4}{|l|}{ Inter-catchment areas } \\
\hline Arab \& Ziqlab (AB21) & 5 & 1 & 6 \\
\hline Ziqlab \& Jurm (AB22) & 3 & 1.5 & 4.8 \\
\hline Jurm \& Yabis (AB23) & 1.5 & 0.0 & 1.5 \\
\hline Yabis \& Kufranja (AB24) & 0.1 & 1.3 & 1.4 \\
\hline Kufranja \& Rajib (AB) & 0.2 & 1.2 & 1.4 \\
\hline Rajib \& Zerka (AB10) & 0.1 & 0.3 & 0.4 \\
\hline Zerka \& Shueib (AB25) & 3.5 & 0.0 & 3.8 \\
\hline Shueib \& Kafrain & 2 & 0.4 & 2.4 \\
\hline Kafrain \& Hisban (AB26) & 0.0 & 1.3 & 1.3 \\
\hline Hisban \& Udheimi (AP2) & 0.34 & 0.3 & 0.64 \\
\hline
\end{tabular}

Table 4. Dams on side wadis of the eastern Lower Jordan Valley area [19].

\begin{tabular}{ccc}
\hline Dam & Capacity [MCM] & Year of Construction \\
\hline Wahda on the Yarmouk & 100 & 2007 \\
El Arab & 20 & 1989 \\
Ziqlab & 4.3 & 1966 \\
Kufranja & 8.0 & 2016 \\
King Talal Dam (Zerqa River) & 89 & 1977 Raised in 1989 \\
Shueib & 2.5 & 1968 \\
Kafrain & 7.5 & 1968 Raised in 1996 \\
Yabis & 7 & Under Study \\
Karamah (in the Jordan Valley) & 55 & 1995 \\
\hline
\end{tabular}




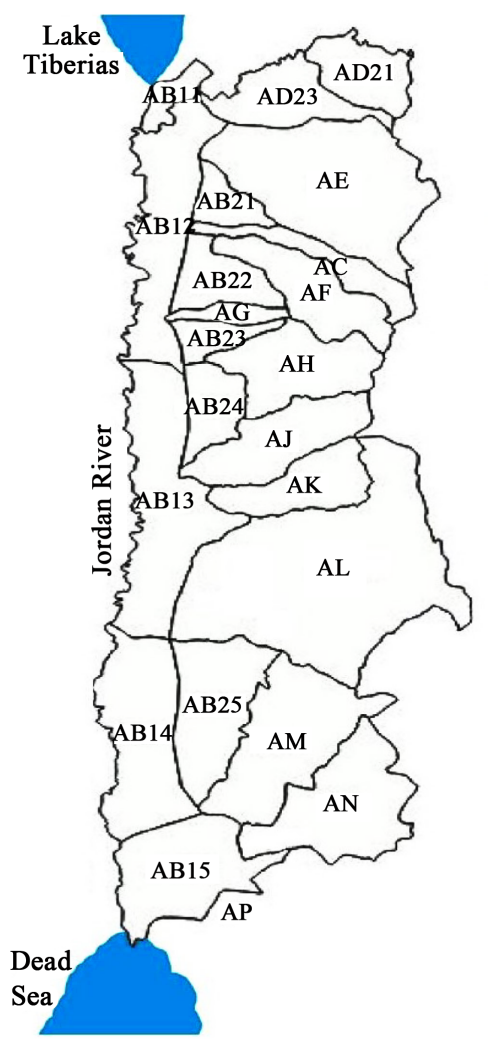

\begin{tabular}{|c|c|c|}
\hline \multicolumn{3}{|l|}{$\bigwedge_{1: 500,000}^{\mathrm{N}}$} \\
\hline \multicolumn{2}{|c|}{ Catchment and Inter-catchments } & \multirow{2}{*}{$\begin{array}{l}\text { Area } \\
{\left[\mathrm{Km}^{2}\right]}\end{array}$} \\
\hline Name & Code & \\
\hline Yarmouk triangle & $\mathrm{AB} 11$ & 35 \\
\hline Yarmouk - Yabis & $\mathrm{AB} 12$ & 107 \\
\hline Yabis - Zarqa & $\mathrm{AB} 13$ & 197 \\
\hline Zarqa - Shueib & $\mathrm{AB} 14$ & 140 \\
\hline Shueib - Dead Sea & $\mathrm{AB} 15$ & 127 \\
\hline Wadi Al-Arab - Ziglab & AB21 & 98 \\
\hline Ziglab - Jurm & $\mathrm{AB} 22$ & 49 \\
\hline Jurm - Yabis & $\mathrm{AB} 23$ & 27 \\
\hline Yabis - Kufranja & AB24 & 73 \\
\hline Zarqa - Shueib & $\mathrm{AB} 25$ & 141 \\
\hline Teiba & $\mathrm{AC}$ & 87 \\
\hline Yarmouk Jordan & AD21 & 126 \\
\hline Yarmouk Jordan & AD23 & 140 \\
\hline Wadi Al-Arab & $\mathrm{AE}$ & 167 \\
\hline Ziglab & $\mathrm{AF}$ & 106 \\
\hline Jurm & AG & 22 \\
\hline Yabis & $\mathrm{AH}$ & 124 \\
\hline Kufranja & AJ & 111 \\
\hline Rajib & $\mathrm{AK}$ & 82 \\
\hline Shueib & AM & 178 \\
\hline Kafrain & AN & 209 \\
\hline Hisban & Ap & 82 \\
\hline
\end{tabular}

Figure 6. Surface water catchments of the eastern side of the Lower Jordan Valley area, their names, codes and catchment areas [18].

Table 5. Average discharges of catchment areas lying downstream of existing dams constructed on eastern side wadis of the Lower Jordan Valley area.

\begin{tabular}{cccc}
\hline \multirow{2}{*}{ Catchment areas downstream of } & \multicolumn{3}{c}{ Flow in $[\mathrm{MCM} / \mathrm{yr}]$} \\
\cline { 2 - 4 } & Flood & Base & Total \\
\hline Wadi Arab Dam & Negligible & 0.0 & 0.0 \\
Ziqlab Dam & 0.5 & 0.0 & 0.5 \\
King Talal Dam & 0.7 & 0.0 & 0.7 \\
Shueib Dam & Negligible & 0.0 & 0.0 \\
Kafrain Dam & Negligible & 0.0 & 0.0 \\
\hline
\end{tabular}

The banks of the JR are built of the Lisan Formation which in the southern half of the Lower JV contains salty groundwater and itself contains soluble salts (gypsum and halides). Therefore the groundwater which flows towards the JR becomes gradually salty the closer it moves towards the JR course. The alluvial fans contain fresh water in their apex areas and salty water in their toe areas.

\section{Aquifer Characteristics}

Some hydraulic characteristics of the alluvial deposits and their water physical parameters in the study area were obtained by field testing. 


\subsection{Infiltration Tests}

The results of infiltration tests in the excavated quarry proposed for MAR are given in Table 6, for the natural soil conditions of silt and marl accumulations at the bottom of the pool.

The infiltration tests showed that the weighted average infiltration rate (with a total duration of $420 \mathrm{hrs}$.) was $1.36 \mathrm{~mm} / \mathrm{hr}$., which considering the accumulated silt in the excavation during around 40 years is relatively high. Removing the silt from the excavation bottom is expected to increase the infiltration rates by many folds as recent dug pits detailed below show.

Infiltration tests in dug pits $30 \times 30 \mathrm{~cm}$ and $40 \mathrm{~cm}$ deep (removal of soil and silt accumulated at ground surface. Pits walls and sides consist of sand and gravel) (Figure 7).

\subsection{Porosity}

Porosity testing was carried out by excavating soils, measuring excavated volume, weighing the excavated material, determining material density and calculating volume of solids.

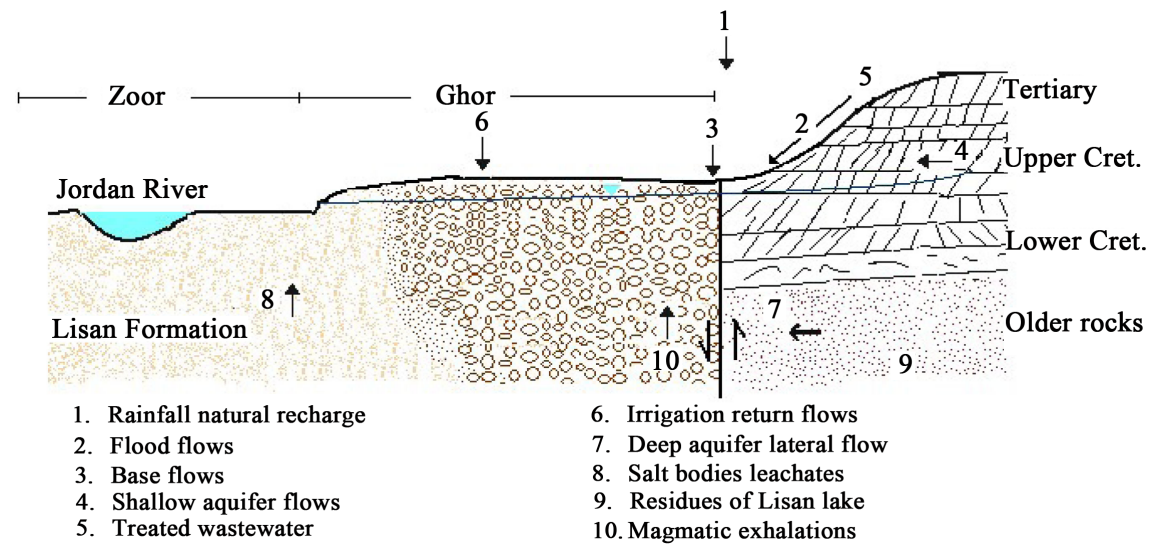

Figure 7. Schematic E-W geological cross-sections extending from the eastern mountains to the Jordan River in the west showing the different water sources in the JV area.

Table 6. Results of infiltration tests in the quarry excavation in Suleikhat area.

\begin{tabular}{cccc}
\hline Date & Drop in water level [mm] & Time $[\mathrm{hrs}]$ & Drop in water level $[\mathrm{mm} / \mathrm{hr}]$ \\
\hline 21-23 Dec. & 40 & 36 & 1.67 \\
4-8 Jan. & 115 & 95 & 1.21 \\
8-9 Jan. & 35 & 23 & 1.52 \\
13-14 Jan. & 45 & 25 & 1.80 \\
16-17 Jan. & 45 & 24 & 1.88 \\
18-21 Jan. & 90 & 71 & 1.27 \\
21-25 Jan. & 120 & 98 & 1.22 \\
3-4 Feb. & 50 & 26 & 1.92 \\
10-11 Feb. & 30 & 22 & 1.36 \\
Totals & 570 & 420 & Weighted av. $1.36[\mathrm{~mm} / \mathrm{hr}]$. \\
\hline
\end{tabular}


Excavated volume of the ground was measured by digging and covering with suitable plastic sheet, filling it with water and measuring the volume of that water. In the case at hand, it was $5230 \mathrm{~cm}^{3}$.

Volume of solids as determined in the laboratory immersion and substitution of water was $4450 \mathrm{~cm}^{3}$ weight of solids after drying $11,500 \mathrm{~g}$.

Density of grains $=2.58 \mathrm{~g} / \mathrm{cm}^{3}\left(11.500 \mathrm{~g} / 4.450 \mathrm{~cm}^{3}=2.58 \mathrm{~g} / \mathrm{cm}^{3}\right)$;

This gives a porosity of $15 \%\left(5.230-4.450=780 \mathrm{~cm}^{3} / 5.230=15 \%\right)$.

This porosity is relatively high (knowing that the soil consists of sandy silty gravel). The average of 8 porosity measurements in the gravel pit was $16.5 \%$ ranging between $12.3 \%$ and $24.6 \%$ which shows the capability of the aquifer to accommodate recharge water.

\section{Hydrochemical Characteristics}

Different mechanisms and genesis pathways govern the chemical composition of the waters in the Jordan Valley area. Dust in the atmosphere, high evaporation rates, salt deposits, remnants of ancient salt lakes, formation water and human activities are some of the factors affecting the water quality. In Figure 7 the general sources of the different water qualities in the eastern Lower Jordan Valley are given. Not all of them do necessarily exist in each sub-area of the Jordan Valley. Details are to be found under the chapter 7 results of geological and geophysical surveys.

\subsection{Precipitation Water}

The location of the rainwater collection site for chemical analyses lies in Deir Alla in the central part of the Jordan Valley.

The measurements on 25 samples with precipitation amounts ranging from $0.1 \mathrm{~mm}$ to $29 \mathrm{~mm}$ show that the electric conductivity of the samples ranged between 41 and $500 \mu \mathrm{s} / \mathrm{cm}$ with a weighted average of $163 \mu \mathrm{S} / \mathrm{cm}$ [21] (Table 7).

The $\mathrm{pH}$ of the rain water samples ranged from 7 to 8.7 with an average of 7.45, only one out-raining sample had a value of 6.5 .

The dominant cat ions are calcium, sodium, magnesium and potassium and the dominant anions are chloride, bicarbonate and sulphate respectively. The concentration of nitrates ranged from 0.5 to $7.7 \mathrm{mg} / \mathrm{l}$ with an average of $3.6 \mathrm{mg} / \mathrm{l}$.

Dust in the atmosphere consists of carbonates, sulphates and other mineral which are made responsible for the relatively high $\mathrm{pH}$ value of the water.

\subsection{Surface Water}

The surface water of the Jordan Valley which originates from the eastern side wadis and the Jordan River itself consists of two components; flood and base flow. The flood flows have normally electric conductivity values ranging from 180 to around $300 \mu \mathrm{S} / \mathrm{cm}$ with $\mathrm{pH}$ values of 8.2 to 9.2 and a nitrate content of 3 to $20 \mathrm{mg} / \mathrm{l}$ (Table 7). The major components are calcium carbonate and sulphate whereas sodium chloride ranks as second in dominance with $\mathrm{Ca}^{2+}>\mathrm{Mg}^{2+}>\mathrm{Na}^{+}$ and $\mathrm{Cl}^{-}>\mathrm{HCO}_{3}^{-}>\mathrm{SO}_{4}^{2-}$. 
Table 7. Physico-chemical characteristic of rain, surface and groundwater, treated effluents and irrigation return flows in the Jordan Valley area [in meq/l, $\mathrm{NO}_{3}$ in $\left.\mathrm{mg} / \mathrm{l}\right]$.

\begin{tabular}{|c|c|c|c|c|c|c|c|c|c|c|c|}
\hline Sample type & Sample Name & $\mathrm{EC}[\mu \mathrm{S} / \mathrm{cm}]$ & $\mathrm{pH}$ & $\mathrm{Ca}^{2+}$ & $\mathrm{Mg}^{2+}$ & $\mathrm{Na}^{+}$ & $\mathrm{K}^{+}$ & $\mathrm{Cl}^{-}$ & $\mathrm{SO}_{4}^{2-}$ & $\mathrm{HCO}_{3}^{-}$ & $\mathrm{NO}_{3}^{-}$ \\
\hline \multirow{2}{*}{ Rain } & Deir Alla Rain & 163 & 7.5 & 0.7 & 0.04 & 0.31 & 0.03 & 0.6 & 0.3 & 0.55 & 3.6 \\
\hline & Wadi Nahda & 278 & 8.7 & 1.62 & 1.1 & 0.37 & 0.3 & 1.79 & 0.83 & 1.16 & 3.0 \\
\hline \multirow{5}{*}{$\begin{array}{l}\text { Flood } \\
\text { water }\end{array}$} & Wadi Suleihlat & 213 & 9.2 & 0.93 & 0.62 & 0.4 & 0.05 & 0.4 & 0.65 & 0.84 & 4.0 \\
\hline & Wadi Aarda & 291 & 8.2 & 1.5 & 1.0 & 0.44 & 0.12 & 0.63 & 0.72 & 1.15 & 20 \\
\hline & Side Wadis Kafrain & 183 & 8.3 & 1.6 & 0.2 & 0.29 & 0.08 & 0.3 & 0.18 & 1.47 & 3.21 \\
\hline & Kureima & 642 & 8.6 & 2.85 & 1.88 & 2.19 & 0.16 & 1.35 & 0.81 & 3.31 & 12 \\
\hline & Ziglab & 680 & 8.3 & 3.35 & 3.17 & 0.99 & 0.1 & 2.35 & 0.5 & 4.64 & 16 \\
\hline \multirow[t]{3}{*}{ Base Flow } & Yabis & 830 & 8.5 & 2.8 & 3.5 & 1.79 & 0.1 & 2.2 & 2.48 & 3.35 & 19 \\
\hline & Kufranja & 732 & 8.2 & 2.56 & 3.44 & 1.31 & 0.1 & 1.6 & 1.1 & 4.0 & 45 \\
\hline & Arda & 770 & 7.7 & 2.37 & 3.12 & 1.93 & 0.26 & 3.4 & 2.67 & 1.4 & 10 \\
\hline \multirow[t]{2}{*}{$\begin{array}{c}\text { Irrigation } \\
\text { Return Flow }\end{array}$} & & 7.770 & 8 & 15.1 & 21.6 & 40.6 & 3.07 & 50 & 16.2 & 5.62 & 55 \\
\hline & Irbid & 1.950 & 7.3 & 4.5 & 2.19 & 10 & 1.2 & 8.15 & 2 & 10 & 1.38 \\
\hline \multirow{6}{*}{$\begin{array}{l}\text { Treated } \\
\text { waste } \\
\text { water }\end{array}$} & Salt (Shueib) & 1.195 & 7.2 & 4.1 & 2.04 & 5.13 & 0.76 & 4.7 & 1.24 & 6.59 & 2.5 \\
\hline & Wadi Sir (Kafrain) & 1.365 & 7.4 & 3.7 & 2.52 & 7.12 & 0.83 & 8.05 & 1.52 & 4.3 & 1.0 \\
\hline & Fuheis & 1.629 & 7.5 & 2.4 & 3.11 & 8.3 & 0.98 & 7.5 & 1.53 & 6.8 & 6.11 \\
\hline & Adasiya 1 & 860 & 6.8 & 5.50 & 3.25 & 0.11 & 0.85 & 1.32 & 0.37 & 6.45 & 0.12 \\
\hline & Adasiya 4 & 2.64 & 7.3 & 7.41 & 6.48 & 0.49 & 13.1 & 15.9 & 5.50 & 5.71 & 24.3 \\
\hline & Waqqas w.l & 735 & 7.1 & 3.5 & 3.68 & 0.07 & 1.74 & 1.18 & 1.86 & 5.65 & 0.03 \\
\hline \multirow{8}{*}{$\begin{array}{l}\text { Jordan } \\
\text { Valley } \\
\text { North }\end{array}$} & Wadi Taybeh & 814 & 8.4 & 3.24 & 3.13 & 0.07 & 1.74 & 1.28 & 1.46 & 5.23 & 0.05 \\
\hline & Sofara w. & 590 & 7.8 & 2.21 & 3.13 & 0.07 & 1.74 & 1.47 & 0.94 & 4.19 & 0.05 \\
\hline & Suleikhat w. 4 & 1.11 & 7.6 & 3.68 & 3.50 & 0.13 & 2.61 & 2.95 & 1.29 & 4.61 & 0.44 \\
\hline & Suleikhat w.1 5 & 570 & 7.6 & 2.58 & 2.39 & 0.07 & 1.74 & 1.28 & 1.77 & 3.98 & 0.04 \\
\hline & Wahadneh w. & 771 & 7.4 & 3.87 & 2.58 & 0.15 & 1.3 & 1.67 & 0.47 & 4.81 & 0.55 \\
\hline & Kraimeh w. 3 & 835 & 7.5 & 3.5 & 2.68 & 0.1 & 2.17 & 1.77 & 1.29 & 5.03 & 0.22 \\
\hline & Karama Farmers Society & 4.218 & 7.4 & 10.3 & 14.17 & 0.65 & 18.1 & 32.3 & 5.72 & 5.55 & 52.8 \\
\hline & Sukhnat Shuna & 1.119 & 7.3 & 3.86 & 3.55 & 0.18 & 3.64 & 4.90 & 1.51 & 4.41 & 14.5 \\
\hline \multirow{3}{*}{$\begin{array}{l}\text { Alluvial } \\
\text { deposits } \\
\text { groundwater }\end{array}$} & Nawwaf Udwan S. Shuna & 2.550 & 7.1 & 7.38 & 8.59 & 0.47 & 17.8 & 10.1 & 2.85 & 5.53 & 36.4 \\
\hline & $\begin{array}{c}\text { Abd Al Karim } \\
\text { Abu Bakr S. Shuna }\end{array}$ & 3.216 & 7.2 & 9.42 & 10.88 & 0.47 & 12.0 & 23.5 & 3.93 & 4.85 & 51.5 \\
\hline & Hazim Nuseiba Kafrain & 1.122 & 7.5 & 7.45 & 4.41 & 0.18 & 3.55 & 4.10 & 2.39 & 4.51 & 41.1 \\
\hline \multirow[t]{2}{*}{$\begin{array}{c}\text { Jordan } \\
\text { Valley South }\end{array}$} & Ali Al Salem Kafrain & 3.622 & 7.3 & 9.2 & 10.62 & 0.91 & 16.2 & 23.3 & 8.17 & 5.94 & 45.8 \\
\hline & Baggurieh Spring & 622 & 7.4 & 3.88 & 2.0 & 0.6 & 0.07 & 1.47 & 0.77 & 3.58 & 32 \\
\hline \multirow[t]{2}{*}{$\begin{array}{l}\text { Upper aquifer } \\
\text { lateral flows }\end{array}$} & Azraq Spring & 514 & 7.2 & 3.58 & 1.6 & 0.65 & 0 & 1.48 & 0.55 & 3.31 & 25 \\
\hline & Jarban Spring & 974 & 7.9 & 5.78 & 2.19 & 0.86 & 0.17 & 2.68 & 0.3 & 4.85 & 54 \\
\hline
\end{tabular}




\begin{tabular}{|c|c|c|c|c|c|c|c|c|c|c|c|}
\hline \multicolumn{12}{|l|}{ Continued } \\
\hline & Kafrain Spring & 653 & 8.1 & 3.1 & 2.04 & 1.83 & 0.2 & 1.6 & 2 & 3.46 & 24 \\
\hline & Himma Spring & 813 & 7.0 & 4.37 & 2.52 & 1.4 & 0.1 & 1.45 & 1.2 & 5.93 & 12 \\
\hline & Waqqas Spring & 704 & 6.9 & 3.1 & 3.11 & 1.21 & 0.1 & 1.23 & 0.68 & 5.62 & 0.0 \\
\hline $\begin{array}{c}\text { Lisan } \\
\text { Marl water }\end{array}$ & Lisan Marl water & 18.290 & 7.8 & 33 & 41.2 & 113 & 6.39 & 138 & 53.6 & 4.57 & 145 \\
\hline \multirow{2}{*}{$\begin{array}{c}\text { Deep } \\
\text { aquifer water }\end{array}$} & $\begin{array}{l}\text { Deep mountain aquifer; } \\
\text { Deir Alla }\end{array}$ & 11.650 & 6.0 & 30.5 & 10.7 & 76.3 & 2.58 & 76.5 & 24.2 & 19.5 & 2.5 \\
\hline & $\begin{array}{l}\text { Deep mountain aquifer; } \\
\text { Sweima }\end{array}$ & 6.480 & 6.4 & 15.3 & 9.13 & 38.5 & 2.35 & 41.2 & 9 & 13.9 & 3.6 \\
\hline \multirow{2}{*}{$\begin{array}{l}\text { Water of } \\
\text { salt bodies }\end{array}$} & Qurein (Mallaha) Salt body & 17.1700 & 6.6 & 62.5 & 3153 & 2203 & 340 & 5230 & 525 & 29.8 & 1845 \\
\hline & $\begin{array}{l}\text { Wakid (south of Tiberias) } \\
\text { salt body }\end{array}$ & 40.600 & 8.2 & 73.1 & 32.2 & 381 & 2.91 & 355 & 132 & 19.5 & 2.4 \\
\hline
\end{tabular}

The chemistry of flood waters differs very widely along the Jordan Valley area and is highly affected by land use and human activities that is in addition to the effects of the country rocks.

The base flow water quality depends largely on the aquifers from which the water issues. The upper aquifers belonging to the Upper Cretaceous and younger aquifers produce intermediate water in relation to their salinity of $640 \mu \mathrm{s} / \mathrm{cm}$ to $840 \mu \mathrm{S} / \mathrm{cm}$. The $\mathrm{pH}$ of these waters ranges from 7.7 up to 8.6 and the nitrate content from 10 to $45 \mathrm{mg} / \mathrm{l}$ (Table 7). Generally, the water of this aquifer complex is yearly replenished and its water is of earth alkaline type with prevailing bicarbonates.

Along the lower reaches of the southern Jordan Valley side wadis the base flows originate from the lower aquifers (Lower Cretaceous and older rocks). These waters have generally higher salinities than the water in the upper aquifer that go as high as a few thousand $\mathrm{mg} / \mathrm{l}$. The high salinity is caused by the dissolution of evaporites within the rock sequences or as relicts of the ancestors of the Dead Sea.

One extreme example of that is the base flow of wadi Mallaha which has an electric conductivity value of $18.290 \mu \mathrm{s} / \mathrm{cm}$ (Table 7 ). The high salinity of these base flows is a result of the high contents of sodium chloride.

\subsection{Treated Waste Water}

On the example of four waste water treatment plants directly flowing into the Jordan Valley like Irbid or indirectly after mixing with base and flood flows Shueib, Wadi Sir and Fuheis the waste water is generally of intermediate salinity with EC values around 1.200 to $2.000 \mu \mathrm{S} / \mathrm{cm}$ (Table 8). The $\mathrm{pH}$ values are almost constant of 7.36 to 7.55 and $\mathrm{Na}^{+}>\mathrm{Ca}^{2+}>\mathrm{Mg}^{2+}$ and $\mathrm{HCO}_{3}^{-}>\mathrm{Cl}^{-}>\mathrm{SO}_{4}^{2-}$. The nitrate contents are generally low $1-6 \mathrm{mg} / \mathrm{l}$.

\subsection{Irrigation Return Flows}

Irrigation return flows are, due to high evaporation rates, concentrated on salts. 
Table 8. Concentrations of pollution parameters in the effluents of relevant waste water treatment plants entering the Jordan Valley $[\mathrm{mg} / \mathrm{l}]$.

\begin{tabular}{cccccccccc}
\hline Treatment plant & $\mathrm{PO}_{4}$ & $\mathrm{NO}_{3}$ & $\mathrm{~T}-\mathrm{N}$ & $\mathrm{NH}_{4}$ & $\mathrm{TDS}$ & $\mathrm{TSS}$ & $\mathrm{COD}$ & $\mathrm{BOD}_{5}$ & $\mathrm{pH}$ \\
\hline Irbid & 6.9 & 1.4 & 93 & 80 & 1075 & 144 & 325 & 64 & 7.54 \\
Fuheis & 12.5 & 6.1 & 20 & 16 & $897+$ & 82 & 130 & 39 & 7.36 \\
Salt & 10.6 & 2.5 & 59 & 51 & 875 & 39 & 86 & 42 & 7.44 \\
Wadi Sir & 13.6 & 1.0 & 85 & 62 & 828 & 32 & 142 & 61 & 7.52 \\
\hline
\end{tabular}

Their salinities depend on irrigation frequency, type of soils and crops. An example given in Table 9 refers to a sample collected west of Deir Alla from the drainage system of irrigation return flows originating from a series of farming areas with a variety of soil types, crops and irrigation frequencies. The salinity of $7.770 \mu \mathrm{S} / \mathrm{cm}$ is high, but the sample may have been affected by the Lisan Formation underlying the area. Zarqa River in its lower reaches used, before becoming a discharge channel for desalination brines, to discharge during summer times water with a salinity of around $5.600 \mu \mathrm{S} / \mathrm{cm}$ which better reflects the quality of irrigation return flow waters. In such water sodium chloride is the dominant dissolved salt with $\mathrm{Na}>\mathrm{Ca}^{2+}>\mathrm{Mg}^{2+}>\mathrm{K}^{+}$and $\mathrm{Cl}^{-}>\mathrm{SO}_{4}^{2-}>\mathrm{HCO}_{3}^{-}$. The nitrate content is high $55 \mathrm{mg} / \mathrm{l}$ but it decreases along the flow course.

\subsection{Groundwater}

Due to the large extent of the Jordan Valley area, its climatic variability, different surface water resources, mechanisms of flow and water rock interactions in addition to land use practices which differ from one area to another the groundwater qualities show a wide spectrum of types, characteristics and salinities.

Therefore, it is not easy to convey a detailed picture of the situation of the groundwater qualities. None-the-less the general situation is given below.

\subsection{Water in the Alluvial Deposits and Slope Debris}

Alluvial fans in the eastern Jordan Valley area are of two types:

- Older alluvial fans which are separated from their feeding wadis due to the sinistral strike slip movement along the major Jordan Transform fault.

- Recent to sub-recent alluvial fans which are still functioning totally or partly as depositional sites for their feeding wadis. These alluvial fans may partly or totally cover older alluvial fans or be separated from them in accordance with the ages of the older ones and with the speed of the sinistral strike slip movement.

These alluvial fans, as long as they contain fresh water, are the target of artificial recharge schemes. As mentioned above their thicknesses may reach more than $100 \mathrm{~m}$.

The composition of the groundwater in these alluvial fans depends on a variety of factors such as: the source of their groundwater, which may be flood or base flow water, groundwater of the adjacent mountain aquifers flowing laterally 
Table 9. Results of infiltration tests in $40 \mathrm{~cm}$ deep pits.

\begin{tabular}{|c|c|c|}
\hline Excavation number & $\begin{array}{l}\text { Time to empty after filling, } \\
40[\mathrm{~cm}] \text { deep pits }\end{array}$ & Infiltration $[\mathrm{cm} / \mathrm{min}]$. \\
\hline 1 & $3 \mathrm{~min} .15 \mathrm{sec}$. & 12.31 \\
\hline 2 & $3 \mathrm{~min} .19 \mathrm{sec}$. & 12.06 \\
\hline 3 & $5 \mathrm{~min} .7 \mathrm{sec}$. & 7.82 \\
\hline 4 & $4 \mathrm{~min} .30 \mathrm{sec}$. & 8.89 \\
\hline 5 & $3 \mathrm{~min} .53 \mathrm{sec}$. & 10.30 \\
\hline 6 & $4 \mathrm{~min} .57 \mathrm{sec}$. & 8.08 \\
\hline Totals of all pits & $25 \mathrm{~min} .3 \mathrm{sec}$. & $\begin{array}{l}\text { Sum of pits depths } 240 \mathrm{~cm} / \text { time to } \\
\text { empty } 25 \mathrm{~min} .3 \mathrm{sec} .=9.6 \mathrm{~cm} / \mathrm{min} \text {. }\end{array}$ \\
\hline
\end{tabular}

into the alluvial deposits, irrigation return flows, upward moving water from deep saline formations etc. Therefore, the chemistry of the groundwater in these alluvial deposits differs widely from one place to another.

Groundwater in the potential areas for groundwater recharge is generally replenished by flood waters originating in the highlands and flowing into the Jordan Valley. The EC values of these groundwaters range from 570 up to $4.218 \mu \mathrm{s} / \mathrm{cm}$. The $\mathrm{pH}$ value lies between 6.77 and 8.37 and the water is of earth alkaline type with prevailing carbonates or chlorides. If not affected by agricultural practices and infiltrations from cesspools the groundwater with low salinity can be used for drinking purposes after chlorination. Generally, the nitrate concentration is less than $50 \mathrm{mg} / \mathrm{l}$. Only in polluted areas with irrigation return flows this value may be higher. The salinity of the water in the alluvial fans increases generally in a westerly direction, towards the Jordan River course, due to mixing with more salty waters of different origins, especially irrigation return flows, upward leakages from deep saline aquifers and Lisan Formation water.

\subsection{Water in the Lisan Formation (JV3) Unit}

The permeability of the Lisan Formation is very low and can be considered as an aquiclude. But, the high tectonic activity of the Jordan Rift Fault and the dissolution of salts from the Lisan Formation containing gypsum and rock salt (up to $6 \%$ of the volume) resulted in the creation of pathways for the water and hence in higher porosity and permeability of the Formation.

The water which leaks up from the Lisan Formation to the surface is highly saline with salinities reaching $50.000 \mu \mathrm{s} / \mathrm{cm}$. In Table 5 an analysis of the water of a spring originating from Lisan Marls margins in Wadi Mallaha is listed with an EC value of $18.290 \mu \mathrm{s} / \mathrm{cm}$. The water is of calcium-sodium chloride type reflecting the Lisan Lake salty deposits.

Other aquifers and rocks in direct contact with the Lisan Formation receive seepages from the latter which leads to increases in their salinities. Generally, the Lisan Formation, south of Deir Alla is a major source of soil and water salinity in the Jordan Valley area [15]. Where the Lisan Formation crops out or is in con- 
tact with other water bodies high salinity values are expected. Soils covering the Lisan Formation are also highly saline because of upward leakages of salts. Especially severe are the conditions in the westerly and south westerly quarter of the Jordanian part of the Lower Jordan Valley extending from the Zarqa River to the Dead Sea, 2 - $5 \mathrm{~km}$ to the east of the Jordan River course.

\subsection{Groundwater in the Jordan Valley 2 (JV2) Unit}

In this aquifer a variety of water types is found. The quality depends on the source of the groundwater and the mixing ratios with other water types.

- Precipitation or lateral flows from the surrounding Upper Cretaceous aquifers have qualities which resemble those of the alluvial fans water discussed above.

- Mixed JV2 pure water with upward moving more saline water originating from deep Lower and Upper Cretaceous rocks. The salinity of these waters range from $1.500 \mu \mathrm{s} / \mathrm{cm}$ up to $4.500 \mu \mathrm{s} / \mathrm{cm}$. The main components are sodium chloride in areas where the second component comes from Lower Cretaceous and older rocks and calcium carbonates where it comes from Upper Cretaceous rocks. The closer to the foothills of the escarpment the more fresh is the water. The closer to the Jordan River course the less probable to encounter water with salinities of less than $3.000 \mu \mathrm{s} / \mathrm{cm}$ in this type of aquifer. Water in the JV 2 is either of the same composition of the fresh groundwater in the alluvial deposits or a mixture of alluvial deposits groundwater and $\mathrm{Li}$ san water, or deep up-leaking saline water. Very rarely, in very restricted areas, it can be pure JV2 water originating from flood flows or a mixture of alluvial groundwater and laterally flowing fresh Upper Cretaceous groundwater.

\subsection{Saline Groundwater}

\section{Saline groundwater in the Lower Jordan Valley has 3 main sources namely:}

- Salt deposits in the Jordan Valley known from the area lying directly downstream of lake Tiberias (Samach) and in the middle part of the Jordan Valley in Damya area; just south of the confluence of Zarqa River into the Jordan River (Mallaha; Zahrat El Grain)

- Lisan Formation water south of Deir Alla;

- Lateral flows from the mountain Triassic and Jurassic aquifers.

Table 7 includes a few analyses of such waters; from the salt bodies South of Tiberias: Wakid well, from Damiya area, Zahrat Al Qurein and from wells at the mountain foot hills encountering Triassic and Jurassic groundwater flowing laterally into the recent deposits of the Jordan Valley. Groundwater in these sites is of high to very high salinity ranging from 6.4 up to $171 \mathrm{mS} / \mathrm{cm}$, water which can only be used after desalination.

Such water is of sodium-calcium chloride type and indicates dissolution of salt bodies; either Triassic salts or sub-recent salt deposits in the Jordan Valley area.

Water sources for recharge 
In addition to wadi flood and base flows and treated waste water (Composition given in Table 7) King Abdullah Canal water can be considered as a major source for artificial groundwater recharge, especially during floods and when water demand for irrigation is minimal.

The composition of the canal water along its course from the Yarmouk River down to the Dead Sea (No additional water downstream of Zarqa River) is given in Table 10. The average water salinity before mixing with Zarqa River water is in general $<950 \mu \mathrm{S} / \mathrm{cm}$ which, from the point of view of normal physico-chemical composition, is of drinking water quality and hence very appropriate for groundwater recharge.

\section{Results of Geological and Geophysical Surveys}

The sinistral strike slip movements along the JVT caused ancient alluvial fans to be separated from their feeding wadis and therefore, wadis entering the northern part of the Lower JV area lie now further north from the alluvial fans which they formerly deposited. In addition, erosional and depositional processes affecting the alluvial fans obscured them from being observed at ground surface. Slip movements, erosion and deposition have made indirect geologic surveys necessary for locating these alluvial fans, knowing that the fault builds the border between the pre-rifting mountain rocks and the recent alluvial deposits. Therefore, different surveys and techniques have to be onducted to locate the suitable alluvial deposits for groundwater recharge such as: geologic mapping and survey, aerial photographs, vertical geoelectric soundings and well date evaluation.

Geoelectric soundings carried out in the JV area by a number of research studies reveal electric resistivity values which range from as low as $0.10 \Omega \mathrm{m}$ and up to $250 \Omega \mathrm{m}$ [23]-[28]. Only dry top layers of gravel yielded higher resistivity values. Very low values are found in the vicinity of the JR, where the Lisan Marl Formation containing salty water crops out. The low resistivity measured in the area lying immediately east and northeast of the Dead Sea shore is referred to clays saturated with Dead Sea water, with a resistivity of $0.04 \Omega \mathrm{m}$ or water similar to it in respect to its salinity (Table 11).

The Lisan Formation of the Jordan Valley, South of the confluence of Zarqa River contains high percentages of salts of around $6 \%$ and possesses resistivity values similar to those measured in the area north and northeast of the Dead Sea shores of $<1 \Omega \mathrm{m}$ [17] [23].

Electric resistivities of up to $40 \Omega \mathrm{m}$ refer to shales and clays or salty water and were measured in the E-W oriented geoelectric soundings at depths of less than $100 \mathrm{~m}$ below surface and near the ground surface when coming closer to the Jordan River course (Figure 5(b)).

Sands and gravels saturated with fresh water gave resistivities of more than 50 $\Omega \mathrm{m}$. Such resistivities were measured at the mountain foothills in the area west of Rama, Kafrain, Shuna and Karamah, Suleikhat, Yabis, Ziglab, Teibeh and 
Table 10. Physico-chemical characteristics of King Abullah Canal water, its source waters and their mixtures with the Canal water $[22]$.

\begin{tabular}{|c|c|c|c|c|c|c|c|c|c|c|c|c|}
\hline Location & & E. $\mathrm{C} \mu \mathrm{S} / \mathrm{cm}$ & Temp. ${ }^{\circ} \mathrm{C}$ & $\mathrm{pH}$ & $\begin{array}{l}\mathrm{Ca}^{2+} \\
\mathrm{meq} / 1\end{array}$ & $\begin{array}{l}\mathrm{Mg}^{2+} \\
\mathrm{meq} / 1\end{array}$ & $\begin{array}{c}\mathrm{Na}^{+} \\
\mathrm{meq} / \mathrm{l}\end{array}$ & $\begin{array}{c}\mathrm{K}^{+} \\
\mathrm{meq} / \mathrm{l}\end{array}$ & $\begin{array}{c}\mathrm{Cl}^{-} \\
\mathrm{meq} / 1\end{array}$ & $\begin{array}{l}\mathrm{SO}_{4}^{2-} \\
\mathrm{meq} / 1\end{array}$ & $\begin{array}{l}\mathrm{HCO}_{3}^{-} \\
\mathrm{meq} / 1\end{array}$ & $\begin{array}{l}\mathrm{NO}_{3}^{-} \\
\mathrm{meq} / 1\end{array}$ \\
\hline \multirow{3}{*}{ Yarmouk River } & Max. & 1.190 & 29.20 & 8.40 & 4.99 & 5.03 & 4.57 & 0.25 & 4.88 & 4.90 & 4.87 & 0.33 \\
\hline & Min. & 485 & 11.50 & 7.74 & 1.83 & 0.90 & 1.41 & 0.10 & 1.10 & 0.25 & 2.30 & 0.05 \\
\hline & Av. & 945 & 21.02 & 8.07 & 3.38 & 2.56 & 3.38 & 0.17 & 3.30 & 1.91 & 3.87 & 0.19 \\
\hline \multirow{3}{*}{ Mukheibah wells } & Max. & 797 & 29.10 & 8.18 & 3.22 & 4.96 & 2.73 & 0.10 & 1.78 & 1.50 & 5.19 & 0.05 \\
\hline & Min. & 740 & 18.70 & 7.84 & 2.56 & 1.99 & 1.30 & 0.01 & 1.62 & 0.24 & 3.77 & 0.00 \\
\hline & Av. & 770 & 23.46 & 8.01 & 2.89 & 2.96 & 2.05 & 0.07 & 1.72 & 1.07 & 4.52 & 0.02 \\
\hline \multirow{3}{*}{$\begin{array}{c}\text { Mix. KAC + } \\
\text { Mukkeibah wells }\end{array}$} & Max. & 1.212 & 31.80 & 8.35 & 4.83 & 3.22 & 4.78 & 0.20 & 3.89 & 4.74 & 4.87 & 0.30 \\
\hline & Min. & 516 & 13.70 & 7.71 & 2.20 & 1.01 & 0.20 & 0.10 & 1.47 & 1.17 & 2.28 & 0.00 \\
\hline & Av. & 955 & 21.26 & 7.98 & 3.61 & 2.26 & 2.89 & 0.16 & 3.01 & 2.87 & 3.64 & 0.17 \\
\hline \multirow{3}{*}{ Tiberias } & Max. & 1.162 & 29.70 & 8.47 & 2.93 & 5.69 & 5.65 & 0.20 & 6.98 & 1.45 & 2.12 & 0.02 \\
\hline & Min. & 1.070 & 16.70 & 7.85 & 2.03 & 2.33 & 3.91 & 0.15 & 6.47 & 0.37 & 1.58 & 0.00 \\
\hline & Av. & 1.112 & 24.08 & 8.24 & 2.47 & 3.46 & 4.69 & 0.18 & 6.72 & 0.97 & 1.92 & 0.01 \\
\hline \multirow{3}{*}{ Arab Dam outlet } & Max. & 1.711 & 31.80 & 8.84 & 6.84 & 4.58 & 6.80 & 0.63 & 5.55 & 4.74 & 6.72 & 2.80 \\
\hline & Min. & 1.150 & 16.10 & 7.00 & 4.16 & 0.36 & 2.17 & 0.10 & 3.30 & 2.08 & 2.19 & 0.00 \\
\hline & Av. & 1.421 & 23.14 & 7.67 & 5.11 & 3.24 & 4.55 & 0.28 & 4.41 & 3.43 & 4.88 & 0.63 \\
\hline \multirow{3}{*}{$\begin{array}{c}\text { Mix. KAC + } \\
\text { Arab Dam outlet }\end{array}$} & Max. & 1.180 & 30.1 & 8.26 & 3.58 & 5.38 & 5.21 & 0.23 & 5.95 & 1.92 & 4.87 & 0.28 \\
\hline & Min. & 444 & 12.2 & 7.25 & 1.89 & 1.25 & 0.86 & 0.1 & 1.37 & 0.58 & 2.12 & 0.02 \\
\hline & Av. & 958 & 21.13 & 8.02 & 2.84 & 2.71 & 3.51 & 0.17 & 4.28 & 1.30 & 3.15 & 0.12 \\
\hline \multirow{3}{*}{ Ziglab Dam outlet } & Max. & 1.180 & 30.10 & 8.26 & 3.58 & 5.38 & 5.21 & 0.23 & 5.95 & 1.92 & 4.87 & 0.28 \\
\hline & Min. & 444 & 12.20 & 7.25 & 1.89 & 1.25 & 0.86 & 0.10 & 1.37 & 0.58 & 2.12 & 0.02 \\
\hline & Av. & 958 & 21.13 & 8.02 & 2.84 & 2.71 & 3.51 & 0.17 & 4.28 & 1.30 & 3.15 & 0.12 \\
\hline \multirow{3}{*}{ Mix. KAC + Ziglab } & Max. & 1.111 & 30.50 & 8.30 & 4.08 & 6.22 & 4.78 & 0.20 & 5.48 & 2.29 & 5.06 & 0.30 \\
\hline & Min. & 447 & 12.80 & 7.93 & 1.79 & 1.39 & 0.95 & 0.07 & 1.30 & 0.72 & 2.01 & 0.00 \\
\hline & Av. & 939 & 21.35 & 8.12 & 2.90 & 2.60 & 3.23 & 0.16 & 3.63 & 1.46 & 3.24 & 0.12 \\
\hline \multirow{3}{*}{ Wadi Rajib } & Max. & 970 & 31.50 & 9.94 & 5.08 & 3.95 & 2.60 & 0.23 & 2.70 & 1.56 & 4.22 & 1.13 \\
\hline & Min. & 653 & 15.30 & 8.31 & 3.10 & 0.97 & 0.78 & 0.05 & 1.25 & 0.71 & 2.63 & 0.49 \\
\hline & Av. & 832 & 21.92 & 8.76 & 3.99 & 2.63 & 1.61 & 0.15 & 2.11 & 1.14 & 3.56 & 0.78 \\
\hline \multirow{3}{*}{ Deir Alla } & Max. & 1.118 & 32.20 & 8.33 & 3.98 & 5.63 & 4.35 & 0.25 & 6.07 & 2.01 & 4.87 & 0.28 \\
\hline & Min. & 466 & 12.90 & 7.62 & 1.66 & 1.39 & 1.30 & 0.10 & 1.51 & 0.37 & 1.93 & 0.00 \\
\hline & Av. & 937 & 21.49 & 8.03 & 2.82 & 2.75 & 3.32 & 0.17 & 3.99 & 1.34 & 3.30 & 0.12 \\
\hline \multirow{3}{*}{ Zarqa River } & Max. & 1.798 & 34.90 & 8.57 & 55.81 & 33.01 & 108.69 & 6.90 & 132.10 & 44.53 & 23.03 & 0.66 \\
\hline & Min. & 919 & 17.30 & 7.46 & 2.49 & 2.25 & 4.16 & 0.23 & 4.39 & 1.80 & 1.93 & 0.02 \\
\hline & Av. & 1.143 & 25.15 & 7.82 & 24.88 & 15.25 & 49.27 & 3.36 & 56.95 & 24.55 & 9.83 & 0.23 \\
\hline \multirow{3}{*}{$\begin{array}{l}\text { Mix. KAC + } \\
\text { Zarqa River }\end{array}$} & Max. & 2.310 & 27.70 & 8.32 & 6.97 & 4.39 & 9.78 & 0.76 & 10.30 & 4.52 & 6.03 & 1.65 \\
\hline & Min. & 451 & 12.50 & 7.79 & 2.38 & 0.07 & 0.86 & 0.10 & 1.66 & 0.75 & 0.86 & 0.15 \\
\hline & Av. & 1.519 & 19.48 & 8.08 & 4.78 & 2.65 & 5.65 & 0.43 & 6.22 & 2.66 & 4.18 & 0.66 \\
\hline
\end{tabular}


Table 11. Electrical resistivity of geologic formations and water bodies in the eastern Lower Jordan Valley area.

\begin{tabular}{|c|c|c|}
\hline Geologic Formation & Electric resistivity & Remarks \\
\hline $\begin{array}{l}\text { Lisan Marls in the northern } \\
\text { Lower Jordan Valley area }\end{array}$ & $5-10 \Omega \mathrm{m}$ & $\begin{array}{l}\text { Fine-grained fresh water deposits } \\
\text { containing irrigation return flows }\end{array}$ \\
\hline $\begin{array}{l}\text { Lisan Marls in the southern } \\
\text { Lower Jordan Valley area }\end{array}$ & $0.1-5.0 \Omega \mathrm{m}$ & $\begin{array}{l}\text { Fine-grained salt water deposits } \\
\text { composed of up to } 6 \% \text { of salts }\end{array}$ \\
\hline $\begin{array}{l}\text { Salty water containing few } \\
1000 \mathrm{mg} / \mathrm{L} \text { of salts }\end{array}$ & Up to $40 \Omega \mathrm{m}$ & $\begin{array}{l}\text { Salty water found in different } \\
\text { geologic formations }\end{array}$ \\
\hline Shales and clays & $10-40 \Omega \mathrm{m}$ & Containing fresh water \\
\hline Sands and gravels & $50-120 \Omega \mathrm{m}$ & Containing fresh water \\
\hline Wet to dry sand and gravel & 200 up to a few thousand $\Omega \mathrm{m}$ & \\
\hline Dead Sea Water & $0.04 \Omega \mathrm{m}$ & Salt content $>320 \mathrm{~g} / \mathrm{L}$ \\
\hline
\end{tabular}

Adasiya. Alluvial fans yield, in theirapex areas such resistivities indicating the presence of fresh water which supports their use for MAR (Figure 8).

The electrical resistivity of E-W profiles increase from as low as $0.1 \Omega \mathrm{m}$ in the southern Lower Jordan River area to more than $250 \Omega \mathrm{m}$ at the foothills of the escarpment which indicates:

1) Decreasing grain size of sediments from gravels at the mountain foot hillsto clays in the Jordan River course area

2) Increasing water salinities in the same direction.

These conditions strongly support considering the alluvial fans in the JV area for MAR projects. As expected, by accepting the strike slip movement along the JVF, borehole data and geoelectric soundings revealed the presence of obscured alluvial fans in the northeastern part of the Lower JV area separated from any potential feeding wadi.

As a result of the geological, hydrological and geophysical surveys the potentials of different parts of the eastern Lower Jordan Valley area for MAR have been defined as follows:

- High potentiality

- Intermediate potentiality

- Low potentiality and

- Negligible potentiality.

Figure 8 gives the subdivision of the eastern side of the Jordan Valley area according to groundwater recharge potentials. The rechargeable water amounts in the different potential MAR areas were estimated using values of porosities and storage coefficients which were obtained from field tests and pumping tests taking into consideration the extension of rechargeable aquifers, their present groundwater levels and the additionally acceptable water column topping the present groundwater levels in order not to cause water logging which may affect existing infrastructures.

Area 1: Wadi El Arab-Yarmouk area (32 $\left.37^{\prime} 25000^{\prime \prime}-32^{\circ} 40^{\prime} 4500^{\prime \prime}\right)$ 


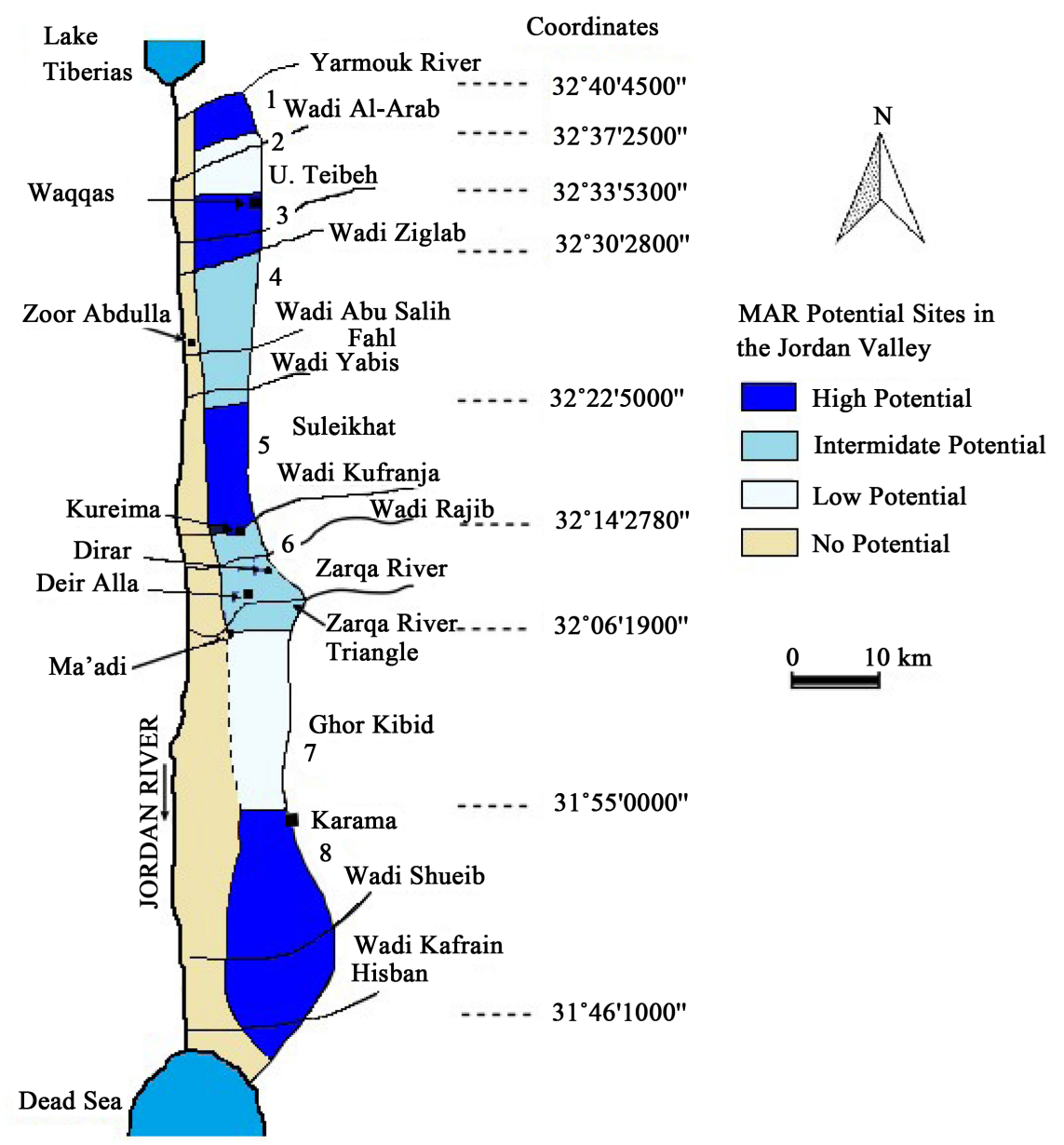

Figure 8. MAR potential sites along the eastern Lower Jordan Valley area.

The recent deposits in this area are built of boulders, gravels and sand of limestone, dolomite, chert and basalt of a thickness of around $100 \mathrm{~m}$, possessing very high porosity and permeability. The groundwater level lies at a few meters under the ground surface, which means that the aquifer has almost no capacity to accommodate additional water. In addition, and due to the very complicated geologic and tectonic up-set of the area and the recent history of the Jordan Rift Valley the composition of the groundwater widely varies from one area to another within tens of meters. Because all of the above, the area can no further be considered for MAR projects.

\section{Area 2: The area around wadi Al Arab (32 $\left.33^{\prime} 5300^{\prime \prime}-32^{\circ} 37^{\prime} 2500^{\prime \prime}\right)$}

The recent sediments in this area are composed of about $40-60 \mathrm{~m}$ of marls and clays from the weathering products of Muwaqqar Bituminous Marl Formation, which covers the catchment area of Wadi Al Arab and its surroundings. The very low permeability of the recent sediments will not allow using these deposits in MAR projects.

Area 3: Wadi Teibeh-wadi Ziglab (32 ${ }^{\circ} 30^{\prime} 2800^{\prime \prime}$ - 32 $\left.33^{\circ} 5300^{\prime \prime}\right)$

The area is built of alluvial deposits consisting of coarse-grained clasts of limestone, chert dolomite and phosphate. The groundwater in the area is a mix- 
ture of locally infiltrating precipitation and flood water and laterally flowing and up-leaking Upper Cretaceous deep confined and mineralized groundwater. The area possesses very high potential for MAR projects, but three problems face such project:

1) The distance of flow towards the Jordan River is short which means eventual loss of the recharged water to the Jordan River;

2) The laterally flowing and up-leaking mountainous aquifers groundwater joining the aquifer from the east is thermal mineralized and reduced containing $\mathrm{H}_{2} \mathrm{~S}$;

3) Intensive use of agrochemicals in the area and their infiltration into the aquifer.

The area can be used for recharge, and can accommodate up to $20 \mathrm{MCM}$ of water, but further studies are necessary to define the fate of recharge water, which can in this area only be used for irrigation.

\section{Area 4: Abu Saleh to Yabis (32 $\left.22^{\prime} 5000^{\prime \prime}-32^{\circ} 30^{\prime} 2800^{\prime \prime}\right)$}

The area is built of alluvial deposits inter-fingering in the east with colluvium debris of originating from the steep eastern mountains. These clastics are composed of coarse-grained limestone chert and dolomite pieces. The E-W extension of the area is $1.5-2.0 \mathrm{~km}$ and the extent of the coarse-grained deposits is very limited in order to allow recharge and recovery. The area's groundwater is fresh as it is fed laterally from the fresh Upper Cretaceous groundwater at the foothills of the mountains. The hydraulic properties and the geologic set-up of the aquifer permit recharge water to very fast flow and discharge into the Jordan River. Although the area possesses high potential for MAR, the fate of the recharged groundwater and its extractability remain somehow doubtful, requiring detailed geometrical and hydraulic aquifer analyses before applying any MAR scheme.

\section{Area 5: Suleikhat area $\left(32^{\circ} 14^{\prime} 2780^{\prime \prime}-32^{\circ} 22^{\prime} 5000^{\prime \prime}\right)$}

This area is built of Pleistocene alluvial fans bordering at the mountain foot hills carbonate, dolomite and chert rocks of Upper Cretaceous age. The groundwater in the alluvial fans receives lateral fresh groundwater flow from the mountain aquifers. The groundwater table lies at a depth of $20-30 \mathrm{~m}$ below ground and hence its capability of accommodating recharge water. The salinity of the groundwater in the up-gradient area is $1.000-1.200 \mu \mathrm{S} / \mathrm{cm}$.

The area possesses very high potential for MAR projects and if fresh water is used for recharge (flood water or King Abdullah Canal water) then the extracted groundwater can be easily used to enhance drinking water supplies. Worth mentioning here is that irrigation in the near foot hill parts of the area is restricted due to the unavailability of irrigation water from KAC water, because the area lies 10 - $15 \mathrm{~m}$ higher than KAC and pumping from the canal to irrigate it is prohibited. This fact offer some guarantee for the not causing harm to the area's groundwater quality.This area can accommodate $5-10 \mathrm{MCM}$ of recharge water.

Area 6: Zarqa River to Suleikhat ( $\left.32^{\circ} 06^{\prime} 1900^{\prime \prime}-32^{\circ} 14^{\prime} 3780^{\prime \prime}\right)$

The area is built of recent and sub-recent alluvial fan deposits composed of 
coarse-grained clastics partly filling ancient Zarqa River flow channels. The area is intensively used for irrigation with Zarqa River water composed of a mixture of treated waste water and flood and base flow water. The groundwater lies at a depth of about $15 \mathrm{~m}$ below ground surface at the mountain foot hills and surfaces westward towards the Jordan River course. The salinity of the groundwater is around $1000-1500 \mu \mathrm{S} / \mathrm{cm}$ and the groundwater contains high concentrations of agro-chemicals. The area hence possesses intermediate potential for MAR projects and the recharged groundwater can after extraction only be used for irrigation. The area can accommodate around $10 \mathrm{MCM}$ of recharge water which at the beginning may partly show increases in salinity, but not to a degree prohibiting their use for irrigation.

\section{Area 7: Karama to Zarqa River area ( $\left.31^{\circ} 55^{\prime} 0000^{\prime \prime}-32^{\circ} 06^{\prime} 1900^{\prime \prime}\right)$}

The eastern part of this area consists of an aquifer composed of Triassic and Jurassic rock debris of sand and silt which receive lateral brackish groundwater flows from the mountain aquifer built by Triassic and Jurassic rocks containing evaporites and brackish groundwater of more than $3.000 \mu \mathrm{S} / \mathrm{cm}$. Its western part is covered by the salty Lisan Marl Formation containing groundwater with a salinity of up to $50.000 \mu \mathrm{S} / \mathrm{cm}$. Due to high salinity of the groundwater in the recent sediments of this area any recharged water will become salinized without any potential use, although the eastern part of the area have the capacity to accommodate several MCM of recharge water. Therefore the area has practically no potential for MAR projects.

Area 8: Dead Sea to Karama area ( $\left.31^{\circ} 46^{\prime} 1000^{\prime \prime}-31^{\circ} 55^{\prime} 0000^{\prime \prime}\right)$

The recent sediments in this area are composed of clastics and alluvial fan deposits consisting of quartz, limestone and chert grains originating from the catchment areas of wadis Udeheimi, Hisban, Kafrain and Shueib and the inter-catchments between them. The groundwater in the area originates from recharge by flood flows, fresh shallow groundwater lateral flows from the Cretaceous rocks, brackish mineralized later flows from the deep Jurassic and Triassic rocks and irrigation return flows. Therefore the groundwater shows high salt content of up to $3000 \mu \mathrm{S} / \mathrm{cm}$ and high concentration of agro-chemicals.

The area possesses very high potential for MAR projects, but the recharged water can after recharge only be used for irrigation or uses with low quality standards such as some industries. The area can accommodate $40-50 \mathrm{MCM}$ of water.

As a summary, the potential storage capacities for recharge water in the different sub areas of the eastern Lower Jordan Valley are given in Table 12.

\section{Conclusions}

The surficial geological formations in the Jordan Valley area consist of recent sediments composed of silts and clay in areas bordering the Jordan River and coarse clastics at the foothills of mountains. The letter was deposited from flood and base flows of side wadis pouring into the Jordan Valley. Also in the Jordan Valley especially during winter times flood waters are available and are not used 
Table 12. Potential recharge water storage capacities in the eastern Lower Jordan Valley area and some remarks about the potential uses of recharged water.

\begin{tabular}{|c|c|c|c|}
\hline Sub Area & $\begin{array}{l}\text { Storage/km N-S } \\
\text { extension }[\mathrm{MCM}]\end{array}$ & $\begin{array}{c}\text { Storage in } \\
\text { subarea [MCM] }\end{array}$ & Remarks \\
\hline Dead Sea Karama & Up to 5 & $40-50$ & $\begin{array}{l}\text { Impaired ground } \\
\text { water quality }\end{array}$ \\
\hline Zarqa River-Suleikhat & 2.5 & 10 & $\begin{array}{l}\text { Present groundwater } \\
\text { salinity } 2500 \mu \mathrm{S} / \mathrm{cm} \\
\text { recharge will improve it }\end{array}$ \\
\hline Suleikhat & 2 & $5-10$ & Drinking water quality \\
\hline Teibeh-Ziglab & 3 & 20 & $\begin{array}{l}\text { Fresh water of } \\
\text { drinking quality }\end{array}$ \\
\hline Al Arab-Yarmouk & $2-3$ & $10-15$ & $\begin{array}{l}\text { Some saline water upward } \\
\text { leakages may cause } \\
\text { deterioration to the } \\
\text { recharged fresh water }\end{array}$ \\
\hline
\end{tabular}

because of the lack of suitable structures to collect them. That is in addition to treated waste water, overspills of dams and floods from precipitation in dam's downstream areas.

These facts allow, in a country suffering of water shortages, to think of making use of such unused water. Water storage in underground reservoirs offers itself as way to store and make use of unused water. Worth mentioning here is that underground storage of water in arid and semiarid regions results in minimizing evaporation losses compared to surface storage, saves the water from direct pollution and accidents, secures the water from eutrophication processes, produces cheaply stored water, and improves groundwater quality having slow turnovers etc.

After studying the alluvial aquifers, their extensions and thicknesses, their potential to accommodate more water, their groundwater qualities and the qualities of potential recharge water, it can be stated that the alluvial deposits of the Lower Jordan Valley area east of the Jordan River has a capability to store some 115 MCM of water which can be recharged in winter times and extracted in summer times if such high water quantities can be made available for that purpose.

Artificially recharged groundwater bodies are expected to be qualitatively upgraded, due to recharge with less salinity water with very low pollutant's contents.

It is recommended to start implementing groundwater artificial recharge by utilizing flood and base flows, in order to improve existing groundwater qualities and alleviate the water shortages in the dry seasons.

If other water sources are to be used in artificial recharge (say treated waste water) its qualitative impacts on the aquifer water have to be studied taking into consideration the water uses after recharge, the probable waters rock interac- 
tions and the environmental impacts.

\section{Acknowledgements}

This work was supported by the United States Agency for International Development (USAID) and United States Geological Survey (USGS) project "Acceleration of Aquifer Storage and Recovery in the Middle East and North Africa (MENA) Region" [grant numbers GI7AS00001].

\section{Conflicts of Interest}

The authors declare no conflicts of interest regarding the publication of this paper.

\section{References}

[1] Salameh, E. (2004) Ancient Water Supply Systems and Their Relevance to Today's Society in Jordan. In: Bienert, H.-D. and Haeser, J., Eds., Men of Dikes and Canals. The Archaeology of Water in the Middle East, Marie Leidorf, Rahden/Westf, Germany, 85-90.

[2] Asano, T. (2016) Artificial Recharge of Groundwater. Elsevier, Amsterdam.

[3] Heviánková, S., Marschalko, M., Chromíková, J., Kyncl, M. and Korabík, M. (2016) Artificial Ground Water Recharge with Surface Water. IOP Conference Series: Earth and Environmental Science, 44, Article ID: 022036. https://doi.org/10.1088/1755-1315/44/2/022036

[4] Huber, A., et al. (2014) Pre-Requirements and Design Criteria for New MAR System in Compliance with EU WFD and GWD (Including Pre-Treatment) Part of D 12.2. DEMEAU.

[5] Bouwer, H. (2002) Artificial Recharge of Groundwater: Hydrogeology and Engineering. Hydrogeology Journal, 10, 121-142. https://doi.org/10.1007/s10040-001-0182-4

[6] Saraf, A.K. and Choudhury, P.R. (1998) Integrated Remote Sensing and GIS for Groundwater Exploration and Identification of Artificial Recharge Sites. International Journal of Remote Sensing, 19, 1825-1841. https://doi.org/10.1080/014311698215018

[7] Peters, J.H. and Jensen, K.H. (1998) Artificial Recharge of Groundwater. In: The Third International Symposium on Artificial Recharge of Groundwater, CRC Press/Balkema, Boca Raton, 1-474.

[8] Chowdhury, A., Jha, M.K. and Chowdary, V.M. (2010) Delineation of Groundwater Recharge Zones and Identification of Artificial Recharge Sites in West Medinipur District, West Bengal, Using RS, GIS and MCDM Techniques. Environmental Earth Sciences, 59, 1209. https://doi.org/10.1007/s12665-009-0110-9

[9] Al-Amoush, H.R. (2006) Hydro-Geophysical Investigations for the Purposes of Groundwater Artificial Recharge in the Jordan Valley Area. Unpublished PhD Dissertation, University of Jordan, Amman.

[10] Wolf, L., Werz, H., Hoetzl, H. and Ghanem, M. (2007) Exploring the Potential of Managed Aquifer Recharge to Mitigate Water Scarcity in the Lower Jordan River Basin within an IWRM Approach. Proceedings of the 6th International Symposium on Managed Artificial Recharge of Groundwater, Phoenix, Vol. 28, 30-46.

[11] Salameh, E., Abdallat, G. and van der Valk, M. (2019) Planning Considerations of 
Managed Aquifer Recharge (MAR) Projects in Jordan. Water, 11, 182. https://doi.org/10.3390/w11020182

[12] Department of Meteorology (DOM), Jordan, Open Files.

[13] Bender, F. (1968) Geologie von jordanien. Gebrüder Burntrãger, Berlin.

[14] Horowitz, A. (1979) The Quaternary of Israel. Academic Press, London.

[15] NRA, Natural Resources Authority (NAR), Mapping Program Sheet, Open Files.

[16] MacDonald (1965) Groundwater Investigation in Dhuleil Area/Jordan UNDP Project.

[17] Bandel, K. and Salameh, E. (2013) Geologic Development of Jordan. Evolution of Its Rocks and Life. University of Jordan Press, Amman.

[18] National Water Master Plan of Jordan (NWMP) (1977).

[19] Water Authority of Jordan (WAJ), Open Files.

[20] Hirzalla, B. (1973) Groundwater Resources in the Jordan Valley. Natural Resources Authority, Amman.

[21] Salameh, E. (1991) Precipitation Water Quality in Jordan. WRSC-Bull. No. 66.

[22] Alkhoury, W.E. and Salameh, E. (2005) The Water Constituents of King Abdullah Canal and Their Role in the Eutrophication Processes. University of Jordan, Amman.

[23] Bundesanstalt für Geowissenschaften (BGR), Bender, F., Flate, H. and Futian, A. (1965) Results of the Hydrogeological and Geoelectrical Survey in the Southern Jordan Valley, Hannover and Amman.

[24] El-Hassan, O. (1999) Geology and Hydrogeology of the Area between Deir Alla and Suleikhat. A Geologic-Geophysical Study for the Potential of Groundwater Artificial Recharge. Unpub. Doctoral Dissertation, M.Sc. Thesis, University of Jordan, Amman.

[25] Sarahney, H. (1999) Residues of Fertilizers and Pesticides in the Water Sources in the Area between Wadi Rayyan and Wadi Yarmouk. Unpubl. Doctoral Dissertation, M.Sc. Thesis, University of Jordan, Amman.

[26] Fehdi, C. (2000) Geology and Hydrogeology of the Area between Suleikhat and Waqqas. A Geologic-Geophysical Study for the Potential of Groundwater Artificial Recharge. Unpubl. Doctoral Dissertation, M.Sc. Thesis, University of Jordan, Amman.

[27] Salameh, E. (2001) The Potential of Groundwater Artificial Recharge in the Jordan Valley Area/Jordan: Selected Contributions to Applied Geology in the Jordan Rift Valley. Freib Forsch. Hefte C, 494, 63-81.

[28] Al-Amoush, H., Salameh, E. and Al-Raggad, M. (2012) Hydro-Geoelectrical Investigation for the Potential of Underground Water Storage along the Lower Reaches of King Abdullah Canal-Deir Alla Area/Jordan. Journal of Water Resource and Protection, 4, 545. https://doi.org/10.4236/jwarp.2012.47064 